'NATURAL CONSERVATIVES?':

EXAMINING THE VOTING ASSOCIATIONS OF ETHNIC AND VISIBLE MINORTY

COMMUNITIES IN THE TORONTO CMA, 2007 TO 2011

\author{
By \\ Brandon Daniel Jacoby \\ B.A., Ryerson University, 2011 \\ A Major Research Paper presented to Ryerson University \\ in partial fulfillment of the requirements for the degree of \\ Master of Arts \\ In the program of \\ Immigration and Settlement Studies
}

Toronto, Ontario, Canada, 2012

(C) Brandon Daniel Jacoby 2012 
AUTHOR'S DECLARATION FOR ELECTRONIC SUBMISSION OF A THESIS

I hereby declare that I am the sole author of this thesis. This is a true copy of the thesis, including any required final revisions, as accepted by my examiners.

I authorize Ryerson University to lend this thesis to other institutions or individuals for the purpose of scholarly research

I further authorize Ryerson University to reproduce this thesis by photocopying or by other means, in total or in part, at the request of other institutions or individuals for the purpose of scholarly research.

I understand that my thesis may be made electronically available to the public. 


\title{
'Natural Conservatives?': Examining the Voting Associations of Ethnic and Visible Minority Communities in the Toronto CMA, 2007 to 2011
}

\author{
Brandon Daniel Jacoby \\ Master of Arts 2012 \\ Immigration and Settlement Studies \\ Ryerson University \\ C Brandon Daniel Jacoby 2012
}

\begin{abstract}
The Conservative Party of Canada attributed its successful breakthrough in the Toronto area during the 2011 Canadian federal election to their engagement of ethnic and visible minority voters, whereas in the past, these voters were associated with the Liberal party. This research study uses spatial and statistical analyses to test patterns of association between the electoral support for the three major parties and presence of ethnic and visible minority communities. The research uses data from the 2006 Census of Canada, as well as the voting results of the 2011 and 2008 federal elections, the 2011 and 2007 Ontario provincial elections and the 2010 Toronto mayoral election. The findings suggest that non-European origin ethnic and visible minority communities are associated with the Liberal party at the federal and provincial levels, but the opposite is true at the municipal level, and the federal Liberals are haemorrhaging support from ethnic and visible minority communities to the Conservatives and NDP. The victories of the federal Conservatives may instead be associated with other factors like vote splitting, low voter turnout, and divisions between urban and suburban areas.
\end{abstract}

Keywords: ethnic vote, party identification, political integration, ethnic minorities, visible minorities 


\section{Acknowledgements}

I would first like to thank my supervisor, Dr. Myer Siemiatycki for his help and guidance during the writing process. Myer pushed me to make this the most sophisticated work possible and I am grateful that he gave me his time in what was a busy summer. I would like to thank my second reader, Dr. Arthur Ross for his insightful comments on my work. Thank you to my friends and classmates for supporting me throughout the MRP process and remind me that there is life outside of grad school. Finally, I would like to thank my family, including new additions Victor and Jackson, as well as Rachelle Marmur for providing me with the support I have needed for the last year and since day one. I could not have done it without you. 


\section{TABLE OF CONTENTS}

\section{List of Chapters}

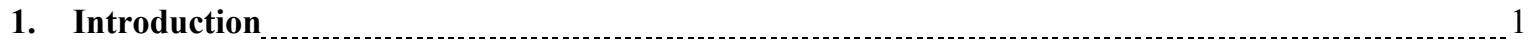

2. Literature Review 3

3. Data and Methods

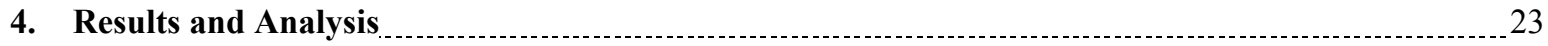

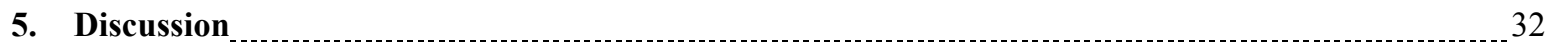

6. Conclusion and Future Directions

Reference List $\ldots \ldots \ldots$

List of Tables

Table 1 - Summary of Ethnic and Visible Minority Groups Under Study in the Toronto CMA _................20

Table 2 - Ethnic Origins and Visible Minorities and the 2011 and 2008 Federal Elections .......................23

Table 3 - Ethnic Origins and Visible Minorities and the 2011 and 2008 Ontario Provincial Elections ...........27

Table 4 - Ethnic Origins and Visible Minorities and the 2010 Toronto Mayoral Election .......................... 30

Table 5 - 2011 Federal Election Results in Bramalea-Gore-Malton 36

Table 6 - 2011 Federal Election Results in Don Valley East

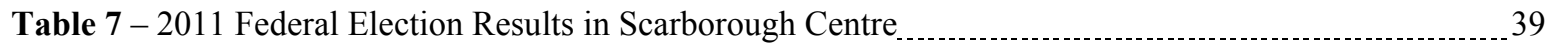

\section{List of Maps}

Map 1 - Federal and Provincial Ridings in the Toronto CMA by Federal Representation, 2011 _................ 18

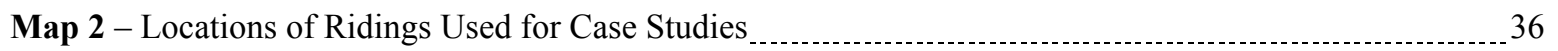

Map 3 - Results of 2010 Toronto Mayoral Election by Ward

\section{List of Appendices}

Appendix A - Vote Totals by Riding for Federal Conservative, Liberal and NDP Candidates, 2008 and 2011.

Appendix B - Vote Totals by Riding for Ontario Provincial Progressive Conservative, Liberal and NDP Candidates, 2007 and 2011

Appendix C - Vote Totals by Ward for Toronto Mayoral Election Candidates, 2010. 51 


\section{CHAPTER 1}

\section{Introduction}

In the 2011 Canadian federal election, the Conservative party made significant breakthroughs in the Greater Toronto Area (GTA) to secure a majority government. While in previous years, the GTA was considered a Liberal stronghold, the Conservatives attributed their victories to years spent courting immigrant and visible minority communities, particularly in the suburban regions of the GTA. Jason Kenney, the Minister of Citizenship and Immigration, has been a prominent participant in ethnic gatherings across the country, courting immigrant and visible minorities communities for the Conservative party. Minister Kenney and the Conservative Party recognized the importance of the so-called "ethnic vote" in tipping the scales in their favour in key ridings. Statistics Canada (2011a) predicts that by $2031,25 \%$ to $28 \%$ of Canadians will be foreign born and nearly a third will be visible minorities. The large size of these communities means that they can form potentially powerful voting blocs that can almost single-handedly prop up or knock down a candidate. If gaining support from immigrant and visible minority communities is going to be the new blueprint for success for Canada's political parties, then it is important that they find ways to effectively engage these communities.

This paper attempts to answer the question of whether the federal Conservative party, led by Prime Minister Stephen Harper, can indeed attribute their electoral success in the Toronto CMA during the 2011 federal election to their engagement of ethnic minority voters and how patterns of ethnic and visible minority electoral support for the three major parties has changed over time and across different levels of government. This 
paper examines the electoral support of ethnic and visible minority voters in the Toronto Census Metropolitan Area (CMA) for the three major political parties, the Conservative Party (or Progressive Conservatives in Ontario provincial politics), Liberal Party, and New Democratic Party (NDP), with emphasis on the 2011 federal election.

The results of the 2011 federal election are compared to the 2011 Ontario election, the 2008 federal election, the 2007 Ontario election, as well as the 2010 Toronto municipal election, where main candidates Rob Ford, George Smitherman and Joe Pantalone could be regarded proxy candidates for the Conservatives, Liberals and NDP, respectively, to see how the voting patterns in ethnic and visible minority communities have changed over time and across different political contexts. Pearson's $r$ is used to determine the extent of the relationship between the ethnic and visible minority makeup of the region's ridings and Toronto's wards. The data used if from the 2006 Census of Canada's profiles of ethnicity and visible minority status and the number of votes for the three main parties or candidates in each electoral district.

The results of the study indicate potential campaign strategies for the three major parties as they continue to battle their rivals in bringing ethnic and visible minority groups into their partisan fold. Furthermore, specific "battleground" ridings that saw a change in party representation following the 2011 federal election are looked at as case studies to determine the extent to which extent the "ethnic vote" contributed to the results of the election. 


\section{CHAPTER 2}

\section{Literature Review}

\section{Political Socialization and Participation in Ethnic and Visible Minority Communities}

In order for a voter to make an informed decision, they must be politically socialized in their jurisdiction so that they understand the issues and candidates and how they affect them. Political socialization is a product of upbringing (Berelson et. al., 1954) and education (Almond and Verba, 1963). Creation of partisan ties is associated with exposure to the Canadian political system (White et. al., 2008) and partisan change is also associated with overall political engagement and familiarity with the policy issues of the day (Wong, 2000; Wolak, 2009).

In the context of immigration, Landolt and Goldring (2010) define the concept of "political culture" as is a toolkit of values and actions that frame the way the strategies that groups choose for self-representation. This toolkit stems from established networks and shared political socialization that occurs in distinct communities (Landolt and Goldring, 2010). There can be stark differences between the political culture of an immigrant's homeland and that of Canada. Bueker (2005) points out that immigrants from countries without an established political culture of democracy, such as China and the states that made up the former USSR, are less likely to vote. Conversely, in a study by Lapp (1999), Greek-Canadians cited the strong political culture of their homeland as one of the main reasons why they follow politics and vote in Canada.

A strong political culture creates opportunities for certain communities to further their own political goals and partner with the mainstream political establishment. For 
example, Chileans in Canada have an established leftist political culture, as many fled the right-wing Pinochet regime, which was attempting to "cleanse" Chile of left-wingers (Landolt and Goldring, 2010). Chileans activist groups are fairly unique among other Latin American activist groups because they are the most overtly political, emphasizing the importance of ideological solidarity and they expressed a willingness to work with leftist organizations in Canada to further their goals (Landolt and Goldring, 2010). This included a long-standing relationship with the left-wing New Democratic Party, as Chileans credited the NDP with having the only legitimate social justice credentials among Canadian political parties to help them end the dictatorship in Chile.

Immigrants and refugees from El Salvador took a similar approach to organizing, mobilizing their networks to combine mutual aid societies as well as transnational politics. Their activism mostly occurred in the United States, but they were able to mobilize and create coalitions between Salvadoran and North American organizations to put pressure on the United States government to end military aid to the regime in El Salvador (Perla, 2010). This resulted in the involvement of a range of non-migrant actors from social justice organizations and other nonprofits in policy issues relating to the region (Chinchilla and Hamilton, 1999). Both Salvadorans and Chileans provided what Perla (2010) called a "signal flare", or call to action, and they were able to mobilize the social and political networks of outsiders to call attention to the plight of their homelands.

One of the main reasons that Chilean and Salvadoran immigrants were so successful integrating themselves politically and having their voices heard was because they were able to wield social capital within and outside their own communities. Social capital is concerned with the value of social ties and how these ties lead to better 
economic and social outcomes (Putnam, 2000). Although immigrants and visible minority communities can and do possess strong networks, they may not provide the "right" kind of social capital that leads to political participation.

The migration process uproots immigrants from their homelands where they can have established social and political ties (Putnam, 2000). Nakhaie (2008) points out that new immigrants need to rebuild their social capital in order to be politically active. Nakhaie goes on to say that dense social networks drive political participation, as they create a breeding ground for political socialization, however, it is important that they reach out beyond their ethnic networks. That is to say that the "bonding" social capital that immigrants and visible minorities create within their networks, while important for settlement, stills keeps them out of the political mainstream. It creates isolated ethnic networks that may not be able to effectively engage politicians and decision makers in the issues that are important to them. Instead, they should focus on "bridging" social capital, to would emphasize building relationships with a variety of stakeholders to further collective goals and be heard by people who may not otherwise hear them. For example, Stoll and Wong (2007) found that immigrants that had "white" (or more "mainstream") people in their social networks were more likely to be politically active.

Of course, forming these networks takes time, which is why length of stay and citizenship are also important factors. Discussions on electoral participation in general conclude that those who are more established in society are more likely to vote, and factors like the mobility of immigrants disrupt their political roots (Nakhaie, 2008; Bass and Casper, 2001). People who are well established in society such as homeowners, older people and married couples have higher stakes in society and politics (Bass and Casper, 
2001). Immigrants make sacrifices and a commitment to Canada when they move to a new country, but due to their lowered socio-economic status they have fewer stakes in Canadian society, and it takes several years to gain the sense of belonging and inclusion that leads to the desire to vote (Bevelander and Pendakur, 2009).

After at least three years of permanent residency in Canada, immigrants can become citizens. Although citizenship is the ultimate end-goal for many new immigrants to Canada, it does not have as important implications as for immigrants to the United States, who are able to access key aspects of the United States' social welfare system only when they become citizens. Immigrants to Canada, by contrast, gain access to the social welfare system when they receive their permanent residency status, so there is less incentive to naturalize, though interestingly, there are higher levels of naturalization in Canada than in the United States. As Bloemraad (2008) demonstrates, the American immigrant integration process is not considered to be the responsibility of the United States government, whereas in Canada, the federal government actively funds programs to integrate immigrants. This highlights one of the key differences between American and Canadian research on political participation of immigrants. American research is concerned with the mechanisms to become a citizen, and it is assumed that citizenship implies active citizenship. Canadian research is concerned with minority representation because the "warm welcome" immigrants to Canada receive helps to put them in a position to participate early on (see Bueker, 2005 for example of American research). The American voter registration experience is also more complicated than in Canada. American citizens are not automatically on the voters list unless they self-register, putting the onus on the citizen, whereas Canadian voters lists are compiled from a list of electors 
according to various records, such as income tax filings or drivers license registrations (Elections Canada, 2012). Immigrants, can opt-in to the register of electors when they fill out their citizenship application (Elections Canada, 2012).

Citizenship does not always imply that a new citizen will vote, however. The benefits of citizenship, such as more freedom to travel, are more tangible than the benefits of voting, and a new citizen's motivation to naturalize may be driven by the nonvoting benefits of citizenship (Bueker, 2005). New citizens lack experience with the Canadian political system and host-country politics (White et. al., 2008; Wong and Tseng, 2008) and this inexperience contributes to their overall lack of participation. As Tossutti (2007a) demonstrates, newcomer status is associated with lower voter turnout. The passage of time creates more political stimuli for an individual, and this causes the participatory practices of immigrant communities to better resemble the general population, causing the short-term effects of elections, such as the party leaders, scandals and issues of the day, to resonate better in immigrant communities (Black, 2009). For example, Nakhaie (2008) found that there was no difference in political participation between native-born Canadians and immigrants who arrived before 1970. Of course, there are differences between the difference waves of immigrants. Most immigrants to Canada before 1970 were white Europeans, whereas 75\% of immigrants that have come since 1985 have come from outside Europe (Nakhaie, 2008).

Voting and running for office, arguably the two most prominent manifestations of democracy, are inaccessible to non-citizens (Claes et. al., 2009). The ability to vote allows immigrants to become part of a political community, as those with similar interests can band together to form voting blocs, and the ethnic social networks 
developed by immigrants and visible minorities can scale one vote into many votes (Bueker, 2005). Furthermore, immigrants and visible minorities who can vote may feel a sense of duty to their ethnic group, and they may vote "on behalf of" those who have yet to become citizens to ensure that their group still has their voices heard (Bueker, 2005). Elections Canada produces materials in 26 different "heritage" languages in order to ensure that non-English or French-speaking citizens understand how to participate in elections (Bevelander and Pendakur, 2009).

Engagement of youth is also an important catalyst for political participation, perhaps even more so in immigrant and visible minority communities. Political participation peaks among 1.5 and $2^{\text {nd }}$ generation immigrants (Lenard, 2005), and the initial turnout decision for those aged 18-30 sets the course for adulthood (Anderson and Goodyear-Grant, 2008).

Families are important filters for political socialization (Torney-Purta et. al., 2007), and youth may turn to their family to seek relevance for political issues that they hear in the news, school, or through social networks (McDevitt, 2005). Parents and grandparents are usually responsible for socializing their children towards politics, but immigrant parents political practices may be based on their home-country politics (Wong and Tseng, 2008) and therefore they are ill-equipped to teach their children, especially when the parents are not citizens themselves (Torney-Purta et. al., 2007).

This puts youth in a unique situation where they can perform political brokering activities and inform the political socialization of their parents (Wong and Tseng, 2008). This "trickle up" effect can reward immigrant and visible minority communities that have a large population of young people, as they can affect the way that their parents vote and 
mobilize to support a particular candidate or issue (McDevitt, 2005). Ethnic media can play a role here, as discussions around the dinner table that stem from television news programs can inform immigrant parents of the issues that are important to their children, who may be better more familiar with the context of important issues on the public agenda (Claes et. al., 2009).

Schools can play an important role in the political development of youth, and Torney-Purta et. al. (2007) suggest that schools should create an environment where students are encouraged to express their opinions, and that attention to specific political issues related to immigrant youth, such as immigration policy or foreign, will help engage immigrant youth and make the issues more relevant to them and their families. Furthermore, schools are an important space for exchanges of ideas between students within their peer groups, which brings a bevy of new opinions and ideas to consider, and therefore creates a better informed future voter (Anderson and Goodyear-Grant, 2008; McDevitt, 2005). Armed with a formal education in civics, they can explain the political institutions to their parents, or encourage their parents to read newspapers and other forms of media, and explain the relevance of laws or policies so that their parents can make informed electoral choices (McDevitt, 2005; Torney-Purta et. al., 2007; Wong and Tseng, 2008). It is worth noting that immigrant youth may choose to interact mostly or exclusively with those from the same cultural background for reasons like language barriers. This may prove to be a detriment to their political socialization.

Even when youth are politically engaged, this does not necessarily translate to voting. Youth in general vote in much lower numbers than adults, but they participate in different ways. While immigrant youth vote less often than their parents, they participate 
in political activities like protesting (Lopez and Marcelo, 2008). The lack of electoral participation in immigrant youth is exacerbated by the cynicism exhibited by youth in general when it comes to politics. After conducting a focus group including both immigrant and native-born youth, Chakera and Sears (2006) found that youth recognized the importance of the principles of democracy, citing historical military struggles to defend democracy, but they were cynical about the effectiveness of their vote. They stated that they did not see that they could make a difference with their vote, that individual members of parliament or members of a legislative assembly had little individual power, and they perceived a lack of difference between the major political parties (Chakera and Sears, 2006). This lack of interest leading to lack of electoral participation is consistent with other studies of motivation to vote among youth (see Anderson and Goodyear-Grant, 2008; Statistics Canada, 2011b; Tossutti, 2007b).

\section{Formation of Partisan Ties - Targeting the "Ethnic Vote"}

Voting is a two-step process, where the actual act of voting is preceded by a decision-making process whereby a voter has to examine the issues that are important to them and how the candidates involved in the election respond to those concerns. This process is even more complex for immigrant and visible minority voters, as they may choose to take into account not only their own individual concerns, but also those of their co-ethnic group (Bueker, 2005). Political parties should therefore address the needs of immigrant and visible minority communities in their policy-making, and they need to recognize that immigrant and visible minority communities have additional policy concerns to those of the general public, such as foreign policy related to their country of origin (Bass and Casper, 2001). This phenomenon is not limited to immigrant and visible 
minority communities alone, as other special-interest groups such as women, the disabled, religious groups or environmental groups that will also emphasize certain policy areas over others.

Ideally, the parties want immigrant and visible minority communities to form partisan ties to their party. Partisanship is the sense of identifying with a political party (Hero et. al., 2000). Like political socialization in general, creation of partisan ties is associated with exposure to the Canadian political system (White et. al., 2008). Partisan change is also associated with overall political engagement and familiarity with the policy issues of the day (Wong, 2000; Wolak, 2009). As stated earlier, immigrants and visible minorities have additional policy concerns compared to the general public, and Nicholson et. al. (2006) point out that they are more likely to be "issue" voters, who vote for or against a candidate based on a limited number of policy issues, usually related to the foreign policy of the candidate's party concerning an immigrant or visible minority group's country of origin. This is dependent on the political knowledge of the individual, and as mentioned earlier in this paper, there is a political knowledge gap between immigrant and visible minority communities and the general population. Of interest is the observation by Nicholson et. al. (2006) that for those who had less information about political issues, their partisan support hinged on the "likeability" of the candidate. For example, they mention that during the 2000 United States presidential election, the Republican Party had success attracting Latino voters because their candidate, George W. Bush was fluent in Spanish, unlike his opponent, and they also engaged in symbolic outreach, such as having a major presence at Latino cultural events. 
Hero et. al. (2000) suggest that if immigrants want to become players in the political system, they should become involved in partisan party activities. Although there is some representation in elected office of immigrants and visible minorities, they do not reflect the makeup of the population. For example, Siemiatycki (2011) found that while visible minorities (which includes both immigrants and non-immigrants) made up over $40 \%$ of the population of the GTA, in the 2011 Ontario election only $34 \%$ of candidates were members of visibility minority communities and just $25 \%$ of those elected were visible minorities. The numbers are even worse at the federal and municipal levels.

Their initial exposure to Canadian politics comes when a new immigrant moves to Canada, and immigrants may have more affinity for the government of the day at the time of immigration (Blais, 2005; Ramakrishnan et. al., 2009). This suggests that many members of Canada's ethnic minority communities have a "default" affiliation with the Liberal party, who are also associated with Canada's multiculturalism policies and more open approaches to immigration (Black, 2009). Indeed, much of the success of the Liberal party, particularly during the Chrétien governments was associated with major support from immigrant communities. Following the 1993 election, nine out of ten Members of Parliament that were members of visible minority communities were part of the Liberal caucus, and the Liberals leaned heavily on community elites within immigrant communities to organize and spread their brand, creating community-wide attachments to the Liberals (Black, 2009). In her study of the 2004 election, the final election won by the Liberals before the Conservatives won power in 2006, Gerber (2006) found the percentage of immigrants in a given riding had profound effects on Liberal party support, particularly in Ontario, where higher numbers of immigrants was associated with high 
levels of Liberal party support. Conversely, ethnic diversity was associated with low levels of support for the Conservatives and NDP (Gerber, 2006).

The big change came in the 2006 election, when the Conservative party shifted their focus to engage Canada's immigrant communities. The Conservatives began to identify immigrants as potential Conservative voters. Conservative leader Stephen Harper articulated this new focus, saying, "These groups are, for the most part, economically and socially conservative people.... My goal is to create a new natural governing party. One of the ways we are going to do that, we are going to displace the Liberals as the party of new Canadians. Because those new Canadians are not liberal in thinking. They are conservative." (O’Neill, 2006). Jason Kenney reiterated this focus during the 2011 election, calling immigrants "natural Conservatives" (Diebel, 2011).

Since then, there has been a complete reversal of political fortunes; the Conservatives have made great strides in reaching out to immigrant communities through both Harper and Jason Kenney. In their study of the 2006 election, Gidengil et. al (2009) partially attributed the defeat of the Liberal party to their loss of visible minority voters. Following the 2008 federal election, just five out of ten visible minority MPs were Liberals, down from nine out of ten in 1993 (Black, 2009).

Since the Conservatives have come to power, they have emphasized family values to attract immigrant voters, and they have made major announcements and policy positions to further their goals, such as the apology to Chinese-Canadians for the head tax and their pro-Israeli stance to attract Jewish voters (Black, 2009). Given that voters have more affinity for the party that was in power at the time of their arrival (Ramakrishnan, 2009), the 2011 election was the first opportunity to vote in a federal election for 
immigrants who immigrated and naturalized since 2006, when the Conservatives came to power. The 2011 election was the time for the Conservatives to strike, particularly in the immigrant-heavy suburbs of the Greater Toronto Area. Indeed, the Conservatives made major inroads in suburban Toronto, winning a number of tightly contested races on their way to a majority government.

In summary, the current research is conflicted on whether the electoral participation of ethnic and visible minority communities is different compared to nativeborn, non-visible minority Canadians. Although there are initial barriers, the Canadian settlement system eventually puts immigrant and visible minority communities in a position to make partisan choices. As explained in the research, relative newcomers have to overcome language barriers, build up their social capital and then learn about policy issues and party positions before they can participate in an election. The relative youth of immigrant and visible minority communities may also play a role, as youth in general have lower participation rates than older adults. More established ethnic and visible minority groups do not face these barriers and their electoral participation is on par with native-born Canadians (see Tossutti, 2007a). In terms of how this influences their political partisan decision, while it is generally accepted that the Liberal party is historically associated with newcomer communities, the Conservatives are making a strong push to attract immigrant and visible minority voters.

In the sections that follow, this paper looks at the results of the 2011 federal election to see whether the Conservative victory in 2011 was associated with more support from immigrant communities, how immigrant voting patterns have changed since the 2008 federal election, whether they are consistent with the 2011 and 2007 Ontario 
elections and the 2010 Toronto mayoral election, and finally, how the ethnic vote influenced the 2010 Toronto municipal election. 


\section{CHAPTER 3}

\section{Data and Methods}

This research attempts to answer the question of whether the partisan support associated with ethnic and visible minority communities is different from the general population. The null hypothesis is that the partisan support associated with ethnic and visible minority in the Toronto CMA is the same as the general population of the CMA, and the alternative hypothesis is that the partisan support associated with ethnic and visible minority communities in the Toronto CMA is different than the general population of the CMA.

The socioeconomic data is from the 2006 Census of Canada and is derived from the answers to two questions from the "long-form" census, which is a sample of $20 \%$ of Canadian households. The first question was 'What were the ethnic or cultural origins of this person's ancestors?', which captured the ethnic origin of respondents. The second question identified whether or not the respondent belongs to one of ten visible minority categories. The results from these two questions were obtained at the census tract level.

This research focuses on the electoral district as the main unit of analysis.

Electoral districts have a set geography and characteristics that allows assumptions to be made about the partisan leanings of the district. There are 45 federal and provincial ridings in the Toronto Census Metropolitan Area (federal and provincial ridings cover the same geography) as well as 44 municipal wards in the City of Toronto. Map 1 shows the electoral results of the 2011 federal election. It is important to note that Map 1 shows the complete boundaries for every riding, so it does not look like a traditional map of the CMA. In addition, some ridings would be considered part of the Greater Toronto Area, 
but the data was collected at the CMA level so any ridings that are not part of the Toronto CMA, such as Guelph, are not included in the study. The total number of votes for the Conservative or Progressive Conservative, Liberal and NDP candidate in each riding from the 2011 federal and provincial elections, the 2008 federal election and the 2007 Ontario provincial election were added to the dataset (see Appendix A and Appendix B). Furthermore, the total number of votes cast for each of the three main Toronto mayoral candidates by municipal ward was also added (see Appendix C). This data is also available at the polling station level, which would provide the smallest possible base of comparison, however the time it would take to process the data, as well as election-toelection changes in polling station locations make it difficult to compile the results from individual polling stations and compare them across time and political contexts.

Using the ArcGIS software program, the boundaries of the 45 ridings and 44 municipal wards were overlaid on top of the boundaries of each census tract. Each census tract that had its centroid, or geometrically centre point, within a riding or ward was assigned to that riding. Although there are some cases where a census tract is part of two or more ridings or wards, assigning census tracts using the centroid method removes ambiguity and the need to divide a census tract among multiple ridings or wards. Furthermore, there is always uneven population distribution within a census tract and it is difficult to determine how to divide the population among the overlapping ridings or wards. Therefore the centroid of selection method was determined to be the fairest way to assign census tracts. Each riding consists of between 20 and 30 census tracts and each ward consists of between 10 and 20 census tracts. 
Map 2 - Federal and Provincial Ridings in the Toronto CMA by Federal Representation , 2011

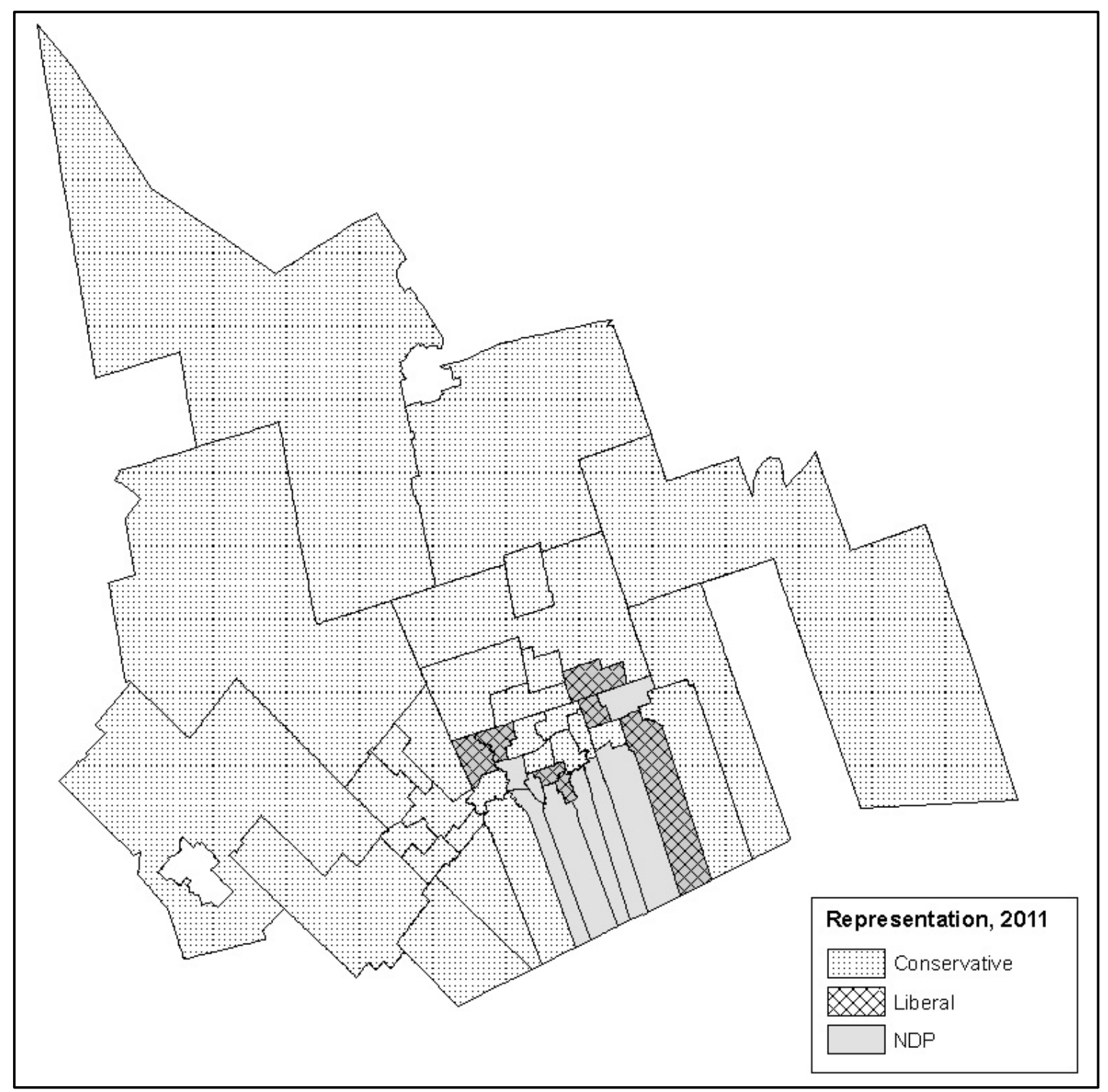

Next, the census tracts were aggregated by the riding or ward to which they belonged, to compile the total respondents for each riding of ward. Therefore, the total number of, for example, Latin Americans was available at the riding level. Only those ethnic origin groups that had a mean population of over 1000 respondents per riding were included in the analysis. This cutoff was used to identify the ethnic groups that had a population substantial enough to form a voting block that could affect election results. There is some overlap between ethnic origin categories. For example, both "Polish" and 
"Russian" are included as sub-categories within the "Eastern European" ethnic origin. There are only ten visible minority groups that are acknowledged by Statistics Canada so all ten are used for this analysis. Table 1 provides a summary of the specific ethnic and visible minority groups looked at and notes the two ridings with the largest residential concentration of each group, with the mean number of residents per riding as well as the standard deviation from the mean. A large standard deviation in relation to the mean implies a large residential concentration of the ethnic or visible minority group in question, where most ridings will have a very small community or no community associated with the group, but a handful of ridings will have a dense residential concentration of the group. Some of the communities that stand out in terms of residential concentration are Russian, Italian, Portuguese, West Asian, South Asian, East Indian and Chinese ethnic origins as well as Chinese, South Asian, West Asian and Korean visible minorities.

Next, the aggregated count of ethnic origins and visible minorities by riding or ward was compiled and the dataset was analyzed using the SPSS software program. The correlation between number of votes for each of the three candidates and the number of members of a given ethnic or visible minority group was obtained as a result of the analysis, and was expressed using Pearson's $r$, making note of statistically significant positive and negative correlations. Pearson's $r$ is a number between 1 and -1 , where values close to 1 imply a high positive correlation, values close to -1 imply a high negative correlation, and values close to 0 imply no correlation either way. Asterisks (*) are used to indicate the confidence of the correlations. Where there is no asterisk, there is no reason to reject the null hypothesis that the partisan support associated with ethnic and 
visible minority in the Toronto CMA is the same as the general population of the CMA.

One asterisk indicates correlations that are statistically significant at the 0.05 level (and

therefore there is $95 \%$ confidence that the null hypothesis can be rejected) and two

asterisks for the 0.01 level (99\% confidence).

Table 2 - Summary of Ethnic and Visible Minority Groups Under Study in the Toronto CMA

\begin{tabular}{|c|c|c|c|}
\hline $\begin{array}{l}\text { Ethnic Origin / } \\
\text { Visible Minority }\end{array}$ & Mean & $\begin{array}{l}\text { Standard } \\
\text { Deviation }\end{array}$ & Notable Residential Concentration \\
\hline British & 29731.44 & 14669.17 & Newmarket --Aurora, Oakville \\
\hline French & 5378.44 & 2612.54 & Newmarket --Aurora, York--Simcoe \\
\hline Canadian & 14541.33 & 6429.12 & York--Simcoe, Newmarket--Aurora \\
\hline Caribbean & 6779.67 & 5281.43 & Brampton West, Bramalea--Gore--Malton \\
\hline Latin American & 2338.44 & 1837.19 & York South--Weston, York West \\
\hline W European & 8465 & 4252.85 & York--Simcoe, Newmarket--Aurora \\
\hline E European & 11154.33 & 6639.92 & Etobicoke--Lakeshore, Thornhill \\
\hline *Polish & 4616.67 & 3087.05 & Etobicoke--Lakeshore, Mississaugua East--Cooksville \\
\hline *Russian & 2276.67 & 2788.68 & Thornhill, York Centre \\
\hline *Ukrainian & 2733.44 & 1870.36 & Etobicoke--Lakeshore, Etobicoke Centre \\
\hline S European & 21022.11 & 14339.53 & Vaughan, Davenport \\
\hline *Italian & 10459.44 & 12261.05 & Vaughan, Oak Ridges--Markham \\
\hline *Portuguese & 4175.11 & 4947.25 & Davenport, Brampton West \\
\hline Jewish & 3141.78 & 6034.61 & Thornhill, York Centre \\
\hline African Origin & 3536.22 & 2701.12 & Etobicoke North, York South--Weston \\
\hline Arab Origin & 2021.33 & 1405.79 & Mississaugua East--Cooksville, Mississaugua--Erindale \\
\hline W Asian & 2867.33 & 3718.5 & Richmond Hill, Willowdale \\
\hline S Asian & 15838.22 & 14589.11 & Bramalea--Gore--Malton, Brampton West \\
\hline *E Indian & 10756.67 & 10798.35 & Bramalea--Gore--Malton, Brampton West \\
\hline Chinese & 11913.67 & 13605.75 & Scarborough--Agincourt, Markham--Unionville \\
\hline $\begin{array}{l}\text { Filipino } \\
\text { Total Visible }\end{array}$ & 4018.56 & 2531.99 & Scarborough--Rouge River, Scarborough Southwest \\
\hline Minorities & 48237.33 & 28834.26 & N/A \\
\hline Chinese VM & 10787.67 & 13324.91 & Scarborough--Agincourt, Markham--Unionville \\
\hline S Asian VM & 15181.33 & 14157.4 & Bramalea--Gore--Malton, Brampton West \\
\hline Black VM & 7793.22 & 6255.96 & $\begin{array}{l}\text { Brampton West, York South--Weston } \\
\text { Scarborough--Rouge River, Mississaugua East-- }\end{array}$ \\
\hline $\begin{array}{l}\text { Filipino VM } \\
\text { Latin American }\end{array}$ & 3810.11 & 2459.35 & Cooksville \\
\hline VM & 2192.78 & 2002.81 & York South--Weston, York West \\
\hline SE Asian VM & 1548.33 & 1426.81 & York West, York South--Weston \\
\hline Arab VM & 1177.89 & 1030.85 & Mississaugua East--Cooksville, Mississaugua--Erindale \\
\hline W Asian VM & 1668.67 & 1908.56 & Richmond Hill, Willowdale \\
\hline Korean VM & 1220.44 & 1655.88 & Willowdale, Thornhill \\
\hline Japanese VM & 413.33 & 341.53 & Toronto Centre, Willowdale \\
\hline
\end{tabular}




\section{Limitations of Research}

The 5-year period between 2006, when the Census data that was used for this study was collected, and 2011, when the last election studied occurred, creates a potential problem where the demographic composition of a riding has undergone significant change since 2006. However, the in-between period is also beneficial because it ensures that noncitizens who were counted in the 2006 census would have become, or had the opportunity to become, Canadian citizens during that time period and vote in the 2010 and 2011 elections.

Secondly, this research does not take into account policy issues or other concerns that lead a voter to support a certain party. This research deals with patterns of association, which do not take into account the issues of the day, the individual candidates or the other factors that influence voter behaviour. It is impossible to pinpoint exactly why an individual or group chooses to support one party over another, and ethnic or visible minority affiliation may not be a motivator to vote for a particular party or candidate.

With this data there is also risk of the ecological fallacy, where the results of the analysis are thought to explain the actions of an individual. The data comes from results associated with a geographic space, not an individual or community. The correlations implied by the data are reflective of the entire Toronto CMA as an aggregate and do not reflect how an individual chooses to vote, nor can the CMA-level data predict correlations of population demographics and voting preferences in any particular constituency. 
Finally, the results of this study could be even more accurate if polling-station level data was used instead of an aggregate of the total number of votes in each riding or ward. Populations are not distributed evenly within a riding or ward, and ethnic and visible minority communities may occupy a small but dense portion of a riding or ward. The results of a polling station that is close to a dense ethnic or visible minority community compared to its neighbouring census tract would be the most accurate in the context of this study, however time constraints meant that there was not enough time to collect and process the data at the polling station level. 


\section{CHAPTER 4}

\section{Results and Analysis}

\section{Federal Elections}

Table 2 shows the results of the statistical analysis for the 2011 and 2008 federal elections.

Table 2 - Ethnic Origins and Visible Minorities and the 2011 and 2008 Federal Elections

\begin{tabular}{|c|c|c|c|c|c|c|}
\hline Ethnic Origin & Con 11 & Lib 11 & NDP 11 & Con 08 & Lib 08 & NDP 08 \\
\hline British & $.338 *$ & .154 & .077 & $.379 *$ & .038 & .130 \\
\hline French & .239 & .180 & .216 & .256 & .077 & .279 \\
\hline Canadian & $.440 * *$ & .078 & -.029 & $.458 * *$ & -.029 & .002 \\
\hline Caribbean & -.282 & .148 & .026 & $-.314^{*}$ & .164 & -.090 \\
\hline Latin American & $-.400 * *$ & .031 & .042 & $-.473 * *$ & .021 & .089 \\
\hline W European & $.427 * *$ & .172 & .092 & $.440 * *$ & .072 & .158 \\
\hline E European & .210 & $.428 * *$ & -.106 & .134 & $.351 *$ & .011 \\
\hline Polish & .199 & $.432 * *$ & -.128 & .142 & $.327 *$ & -.024 \\
\hline Russian & .184 & .219 & -.157 & .084 & .226 & -.080 \\
\hline *Ukrainian & .153 & $.356^{*}$ & -.003 & .132 & .286 & .089 \\
\hline S European & .161 & .214 & .000 & -.057 & .275 & .062 \\
\hline Italian & $.309 *$ & .165 & -.148 & .092 & .246 & -.083 \\
\hline Portuguese & -.169 & .020 & .270 & -.225 & .009 & .249 \\
\hline Jewish & .161 & .116 & -.168 & .084 & .132 & -.103 \\
\hline African Origin & $-.550 * *$ & .049 & .068 & $-.557 * *$ & .032 & .044 \\
\hline Arab Origin & .049 & $.444 * *$ & -.213 & -.066 & $.437 * *$ & -.235 \\
\hline W Asian & .033 & $.319^{*}$ & -.221 & -.062 & $.341 *$ & -.205 \\
\hline S Asian & -.128 & .223 & .001 & -.164 & .272 & -.178 \\
\hline E Indian & -.061 & .237 & -.008 & -.092 & .255 & -.171 \\
\hline Chinese & -.112 & .276 & .135 & -.180 & $.445^{* *}$ & .331 \\
\hline Filipino & -.274 & .278 & -.069 & $-.364 *$ & $.321 *$ & -.178 \\
\hline Total Vis. Minorities & -.290 & $.339 *$ & .048 & $-.374 *$ & $.449 * *$ & -.124 \\
\hline Chinese VM & -.107 & .264 & .133 & -.171 & $.433 * *$ & .014 \\
\hline S Asian VM & -.129 & .220 & -.001 & -.165 & .270 & -.180 \\
\hline Black VM & $-.430 * *$ & .089 & .043 & $-.446 * *$ & .082 & -.032 \\
\hline Filipino VM & -.277 & .266 & -.075 & $-.366^{*}$ & $.307^{*}$ & -.179 \\
\hline Latin Amer. VM & $-.419 * *$ & -.009 & .005 & $-.484 * *$ & -.106 & .212 \\
\hline SE Asian VM & -.291 & .034 & .055 & $-.405 * *$ & .079 & .070 \\
\hline Arab VM & -.008 & $.391 * *$ & -.198 & -.087 & $.353 *$ & -.227 \\
\hline W Asian VM & .013 & .273 & -.210 & -.063 & .288 & -.212 \\
\hline Korean VM & .054 & $.345^{*}$ & -.139 & -.006 & $.313^{*}$ & -.118 \\
\hline Japanese VM & $-.364 *$ & $.394 * *$ & $.374^{*}$ & $-.376^{*}$ & $.413^{* *}$ & $.373^{*}$ \\
\hline
\end{tabular}

*significant and .05 level $* *$ significant at .01 level 
During the 2011 election, votes for Conservative party candidates were significantly and positively associated with the presence of people of British, Canadian, Western European, and Italian ethnic origins. They had positive associations with all of the included European origins, with the exception of Portuguese origin, though not all associations were significant

There were significantly negatively associated with the presence of people of Latin American and African origins and Black and Japanese visible minorities. They had negative or neutral associations with almost all the visible minority categories.

Of note was that the Conservatives had no apparent association with the presence of South Asian voters, despite their victories in the some GTA ridings being attributed to their outreach to South Asian communities. As shown in upcoming case studies and the discussion section, Conservative victories in ridings with large South Asian communities may be attributed to other factors.

Positive support for the Liberal party candidates during the 2011 election was significantly associated with the presence of people of Eastern European, Polish, Ukrainian, Arab, and West Asian (Iranian, Afghani, etc.) ethnic origins, and the presence of visible minorities in general, but specifically Arab, Korean, and Japanese visible minorities.

There were no significant negative associations between Liberal candidates and any ethnic or visible minority group. In fact, the Liberal party's candidates had positive associations with almost all the visible and ethnic minority categories studied, and although not all were significant at the 0.05 level, many were nearing this threshold. 
The New Democratic Party candidates had no significant positive or negative associations with any of the ethnic and visible minority categories studied with the exception of a significant positive association with Japanese visible minorities.

In the 2008 election, votes for Conservative candidates were positively associated with the presence of people of British, Canadian and Western European ethnic origins. They had significant negative associations with people of Caribbean, Latin American, African and Filipino ethnic origins and the presence of visible minorities in general, but specifically Black, Filipino, Latin American and Southeast Asian visible minorities.

The Liberal candidates had positive associations with the presence of Eastern European, Polish, Arab and Chinese ethnic origins as well as visible minorities in general, specifically Chinese, Filipino, Arab, Korean and Japanese visible minorities. They had no negative associations with any of the ethnic or visible minority categories under study, except for very small negative associations with people of Canadian ethnic origin and Latin American visible minorities.

Like the 2011 election, the electoral support for New Democratic Party candidates had no significant positive or negative associations with any of the ethnic and visible minority categories studied with the exception of a significant positive association with Japanese visible minorities.

Looking at the differences between the 2011 and 2008 elections, the Conservative party saw gains nearly across the board. Almost all of the ethnic and visible minority categories under study had more support associated with the Conservative party in the 2011 election than the 2008 election. Of particular note were their gains with people of Italian ethnic origin, where they went from having a mostly neutral association to having 
a significant positive association. This led to a gain among people of Southern European ethnic origin, of which Italian is a sub-category. Their significant positive support remained consistent with British, Canadian and Western European ethnic origins.

The Conservatives continued to have negative associations with Caribbean and Filipino ethnic origins and visible minorities in general, but specifically Filipino and Southeast Asian visible minorities, but the gains made by Conservatives caused the associations to drop from being significantly negative to merely negative.

The Liberals, despite their electoral defeats in 2011, also had many positive increases in association between the two elections. They had gains with people of British, French, Canadian, Western European, Eastern European, Polish, and Ukrainian ethnic origins and Arab and Japanese visible minorities.

However there was also a decrease in the association of the Liberals with many of the non-European ethnic and visible minority origins. Of particular note was the loss in support from people of Chinese and Filipino ethnic and visible minorities. Although they still have positive associations with the Liberal party, they were no longer significant in 2011. The Chinese were especially troublesome for the Liberals, as they went from having associations that were significant at the 0.01 level in 2008 to having a positive but insignificant relationship with Liberal candidates in 2011.

Associations between the NDP and ethnic and visible minorities remained mostly the same between 2011 and 2008. They made gains in association with many of the nonEuropean origins, albeit most of them are still negatively associated with support for the NDP. 


\section{Provincial Elections}

Table 3 shows the results of the statistical analysis for the 2011 and 2007 Ontario provincial elections.

Table 3 - Ethnic Origins and Visible Minorities and the 2011 and 2008 Ontario Provincial Elections

\begin{tabular}{|c|c|c|c|c|c|c|}
\hline Ethnic Origin & PC 11 & Lib 11 & NDP 11 & PC 07 & Lib 07 & NDP 07 \\
\hline British & $.307 *$ & .215 & .062 & $.393 * *$ & .059 & .062 \\
\hline French & .183 & .226 & .203 & .259 & .018 & .135 \\
\hline Canadian & $.376^{*}$ & .128 & -.021 & $.429 * *$ & .050 & -.044 \\
\hline Caribbean & $-.380 *$ & -.057 & .132 & $-.403 * *$ & .002 & -.102 \\
\hline Latin American & $-.525^{* *}$ & -.033 & .162 & $-.555 * *$ & -.102 & .033 \\
\hline W European & $.376^{*}$ & .259 & .052 & $.444 * *$ & .108 & .131 \\
\hline E European & .126 & $.474 * *$ & -.157 & .220 & $.326^{*}$ & .240 \\
\hline Polish & .119 & $.423 * *$ & -.168 & .184 & $.310^{*}$ & .219 \\
\hline Russian & .116 & $.334 *$ & -.210 & .212 & .225 & .036 \\
\hline Ukrainian & .111 & $.358 *$ & -.033 & .171 & .237 & $.331 *$ \\
\hline S European & -.084 & $.309 *$ & .027 & -.224 & $.338^{*}$ & -.034 \\
\hline Italian & .084 & .293 & -.111 & -.075 & $.364 *$ & -.065 \\
\hline Portuguese & -.267 & -.002 & .265 & $-.306^{*}$ & -.060 & -.002 \\
\hline Jewish & .115 & .236 & -.215 & .212 & .140 & .080 \\
\hline African Origin & $-.617 * *$ & -.108 & .191 & $-.593 * *$ & -.169 & -.007 \\
\hline Arab Origin & -.093 & $.322 *$ & -.252 & -.170 & $.524 * *$ & -.149 \\
\hline W Asian & -.009 & $.343 *$ & -.284 & .043 & $.372 *$ & -.116 \\
\hline S Asian & -.248 & .012 & .045 & -.283 & .126 & -.143 \\
\hline E Indian & -.186 & .014 & .040 & -.213 & .101 & -.137 \\
\hline Chinese & -.119 & .230 & .009 & -.166 & $.359^{*}$ & -.092 \\
\hline $\begin{array}{l}\text { Filipino } \\
\text { Total Vis. }\end{array}$ & $-.377^{*}$ & .201 & -.067 & $-.373^{*}$ & $.302 *$ & -.133 \\
\hline Minorities & $-.403 * *$ & .140 & .048 & $-.445 * *$ & .277 & -.146 \\
\hline Chinese VM & -.107 & .225 & .005 & -.153 & $.350 *$ & -.086 \\
\hline S Asian VM & -.248 & .009 & .044 & -.283 & .126 & -.141 \\
\hline Black VM & $-.513 * *$ & -.113 & .176 & $-.516 * *$ & -.103 & -.063 \\
\hline Filipino VM & $-.376^{*}$ & .191 & -.072 & $-.373^{*}$ & $.294^{*}$ & -.126 \\
\hline Latin Amer. VM & $-.530 * *$ & -.079 & .131 & $-.562 * *$ & -.125 & .013 \\
\hline SE Asian VM & $-.455^{* *}$ & -.134 & .162 & $-.532 * *$ & -.039 & .021 \\
\hline Arab VM & -.106 & .226 & -.235 & -.194 & $.444 * *$ & -.150 \\
\hline W Asian VM & -.015 & .290 & -.263 & .033 & $.328^{*}$ & -.126 \\
\hline Korean VM & .056 & $.355^{*}$ & -.210 & .125 & $.310^{*}$ & -.040 \\
\hline Japanese VM & $-.356^{*}$ & $.405 * *$ & .272 & -.233 & .179 & .147 \\
\hline
\end{tabular}

*significant and .05 level **significant at .01 level 
During the 2011 Ontario provincial election, significant positive support for Progressive Conservative candidates was associated with the presence of people of British, Canadian and Western European ethnic origins. They had significant negative associations with the presence of people of Caribbean, Latin American and African ethnic origins, as well as visible minorities in general, but specifically Black, Latin American, Southeast Asian, and Japanese visible minorities.

The Ontario Liberals had significant positive associations with Eastern European, Polish, Russian, Ukrainian, South European, Arab and West Asian ethnic origins, as well as Korean and Japanese visible minorities. They had no significant negative associations with any of the groups under study,

The NDP had no significant positive or negative associations with any of the categories under study, albeit they had negative but insignificant associations with Russian, Jewish, Arab and West Asian ethnic origins and Arab, West Asian, Korean and Japanese visible minorities.

Progressive Conservative support in the 2007 election was associated with people of British, Canadian, and Western European ethnic origins. Significant negative associations were present with people of Caribbean, Latin American, Portuguese, African and Filipino ethnic origins and visible minorities in general, but specifically Black, Filipino, Latin American and Southeast Asian visible minorities.

During the 2007 election, the Liberal party had significant positive support associated with Eastern European, Polish, Southern European, Italian, Arab, West Asian, Chinese and Filipino ethnic origins, as well as Chinese, Filipino, Arab, West Asian and 
Korean visible minorities. They had no significant negative associations with any of the groups under study,

The Ontario NDP only had a significant positive association with Ukrainian ethnic origin and no significant negative associations with any of the groups under study. Between the 2011 and 2007 Ontario provincial elections, the Progressive Conservatives mostly lost support across the board. They maintained consistent significant positive support with British, Canadian and Western European ethnic origins, but also maintained significant negative associations with Caribbean, Latin American and African ethnic origins, as well as visible minorities in general, but specifically Black, Filipino, Latin American and Southeast Asian visible minorities.

The Liberal party made gains in most of the European-origin groups, but lost some support from the non-European ethnic and visible minority groups. They maintained or increased their significant positive support with Eastern European, Polish, Russian, Arab and West Asian ethnic origins, but were no longer significantly positively associated with Italian, Chinese and Filipino ethnic minorities, nor Chinese, Filipino, Arab and West Asian visible minorities, albeit they maintained a positive association with these groups.

Associations between the provincial NDP and ethnic and visible minorities remained mostly the same between 2011 and 2007. They made gains in association with many of the population categories under study, but they lost people of Ukraniain ethnic origin, the only significant positive association they had in 2007. 


\section{Municipal Election}

Table 4 shows the results of the statistical analysis for the 2010 Toronto municipal election.

Table 4 - Ethnic Origins and Visible Minorities and the 2010 Toronto Mayoral Election

\begin{tabular}{|c|c|c|c|}
\hline Ethnic Origin & Ford & Smitherman & Pantalone \\
\hline British & .017 & $.672 * *$ & $.371^{*}$ \\
\hline French & -.152 & $.752 * *$ & $.555^{* *}$ \\
\hline Canadian & .111 & $.516^{* *}$ & .234 \\
\hline Caribbean & .114 & $-.438 * *$ & $-.375^{*}$ \\
\hline Latin American & -.158 & $-.462 * *$ & -.023 \\
\hline W European & -.051 & $.757 * *$ & $.473 * *$ \\
\hline E European & .230 & $.316^{*}$ & .151 \\
\hline Polish & .202 & $.336^{*}$ & .197 \\
\hline Russian & .029 & .213 & .026 \\
\hline Ukrainian & $.397 * *$ & .212 & .172 \\
\hline S European & -.133 & $-.346^{*}$ & .226 \\
\hline Italian & .010 & $-.436^{* *}$ & -.047 \\
\hline Portuguese & $-.322 *$ & -.135 & $.409^{* *}$ \\
\hline Jewish & -.060 & .171 & -.001 \\
\hline African Origin & -.013 & $-.496 * *$ & $-.327 *$ \\
\hline Arab Origin & .132 & -.118 & $-.417 * *$ \\
\hline W Asian & .180 & -.074 & $-.312 *$ \\
\hline S Asian & .220 & $-.323 *$ & $-.467 * *$ \\
\hline E Indian & .227 & $-.334 *$ & $-.477 * *$ \\
\hline Chinese & .050 & -.015 & -.177 \\
\hline Filipino & .251 & -.282 & $-.357^{*}$ \\
\hline Total Vis. Minorities & .181 & $-.413 * *$ & $-.513 * *$ \\
\hline Chinese VM & .050 & -.007 & -.168 \\
\hline S Asian VM & .217 & $-.324 *$ & $-.467 * *$ \\
\hline Black VM & .061 & $-.528 * *$ & $-.384^{*}$ \\
\hline Filipino VM & .250 & -.286 & $-.359 *$ \\
\hline Latin Amer. VM & -.144 & $-.505 * *$ & -.082 \\
\hline SE Asian VM & $-.335^{*}$ & $-.387 * *$ & -.013 \\
\hline Arab VM & .166 & -.192 & $-.426 * *$ \\
\hline W Asian VM & .182 & -.093 & $-.308^{*}$ \\
\hline Korean VM & .241 & .109 & -.081 \\
\hline Japanese VM & -.037 & $.607 * *$ & .272 \\
\hline
\end{tabular}

Rob Ford, the proxy Conservative candidate, received significant positive associations with people of Ukrainian ethnic origin only. He had positive but statistically 
insignificant associations with Eastern European, Polish, South Asian, East Indian and Filipino ethnic origins, and Filipino and Korean visible minorities. He had significant negative association with people of Portuguese ethnic origin and Southeast Asian visible minorities.

George Smitherman, the proxy Liberal candidate, had significant positive associations with people of British, French, Canadian, Western European, Eastern European, and Polish ethnic origins, as well as Japanese visible minorities. He had negative associations with nearly all of the non-European groups under study. Of note were significant negative associations with Caribbean, Latin American, Southern European, Italian, African, South Asian and East Indian ethnic origins, as well as visible minorities in general, but specifically South Asian, Black, Latin American and Southeast Asian visible minorities.

Joe Pantalone, the proxy NDP candidate, had significant positive associations with people of British, French, Western European, and Portuguese ethnic origins. He had significant negative association with people of Arab, West Asian, South Asian, East Indian, and Filipino ethnic origins, as well as visible minorities in general, but specifically South Asian, Black, Filipino, Arab and West Asian visible minorities. 


\section{CHAPTER 5}

\section{Discussion}

\section{Comparing the Elections}

Between October 2010 and October 2011, the city of Toronto had elections for all three levels of government. Municipal elections were held in October of 2010, the federal election was held in May of 2011 and the Ontario election was held in October of 2011. The proximity of these elections creates an opportunity to compare partisan associations across the three levels of government.

In both the 2011 provincial and federal elections, the federal Conservative and provincial Progressive Conservative parties had consistent electoral support associated with the presence of people of British, Canadian and Western European ethnic origins. However, they also had consistent negative support associated with Latin American and African ethnic origins and Black and Japanese visible minorities. Interestingly, the Toronto municipal election turned these results on their head. Rob Ford had no significant support associated with British, Canadian and Western European ethnic origins, nor did he have negative support associated with Latin American and African ethnic origins and Black, Latin American and Japanese visible minorities. As we will see, this may speak to a greater urban-suburban divide in the city that stems from the amalgamation of Toronto and its inner suburbs in 1998.

The Liberal party had significant positive support at the federal and provincial level associated with people of Eastern European, Polish, Ukrainian, Arab and West Asian ethnic origins and Korean and Japanese visible minorities, and no consistent significant negative associations The Liberal proxy candidate in Toronto, George 
Smitherman, was also associated with Eastern European and Polish ethnic origins and Japanese visible minorities, but no apparent association with Arab and West Asian ethnic origins nor Korean visible minorities.

The New Democratic Party has no consistent positive or negative associations with any of the ethnic and visible minority groups under study.

\section{Explaining the 2010 Toronto mayoral election}

One of the more interesting aspects of this data piece was the apparent mismatch between support for the Conservative and Liberal parties at the federal and provincial levels and their proxy candidates in the Toronto municipal election. The Toronto election was the first to occur, having been held in late 2010 , and theoretically set the tone for the subsequent elections.

Before running for mayor of Toronto, Smitherman represented the Toronto Centre riding as a provincial Liberal. In the Toronto election, he might have expected to receive support similar to that of the Ontario Liberal party in the 2007 election. This means that Smitherman would have expected to receive support associated with people of Eastern European, Polish, Southern European, Italian, Arab, West Asian, Chinese and Filipino ethnic origins, as well as Chinese, Filipino, Arab, West Asian and Korean visible minorities. However, the data shows overwhelming negative associations between George Smitherman and almost every non-European origin group under study.

That is not to say that non-European origin voters jumped to support Conservative proxy candidate Rob Ford. In fact, both Ford and NDP proxy candidate Joe Pantalone both had little support associated with non-European origin voters, with Pantalone associated with negative support from many of those groups. Ford only enjoyed 
significant positive support associated with Ukrainian voters, and with a total population of a little over 50000 people in the city of Toronto (which includes people of non-voting age), they would have had to vote en masse for Ford, who won by nearly 100000 votes, in order to have any discernable impact on the election results.

One explanation is that George Smitherman and his team took the ethnic vote for granted. They would have expected support from most ethnic and visible minority communities and instead they focused their engagement efforts on European-origin voters. This is reflected in Smitherman's highly significant support associated with British, Canadian and Western European origin groups, which, as the data shows, are usually associated with support for the Conservative party. Another explanation is that ethnic and visible minority voters did not vote for Ford, but instead against Smitherman. Smitherman was the first openly gay cabinet minister in Ontario and his campaign manager described incidents of homophobia aimed at Smitherman during the election (Kuitenbrouwer, 2010). There are still many countries and regions where homosexuality is taboo, criminalized or generally considered unacceptable, and, although this argument is speculative, his sexual orientation may have contributed to the paucity of support he appeared to receive from some ethnic groups.

Overall, the data shows that Ford did not receive significant support from most ethnic and visible minority communities, but he did benefit from the lack of support associated with Smitherman from those communities. Whoever runs against Ford in the 2014 election will have to take care to engage ethnic and visible minorities at a greater scale than Smitherman's campaign. 


\section{Explaining the 2011 federal election}

Although Stephen Harper's Conservatives attributed their victory to their engagement of immigrant voters, the data shows significant negative associations between Conservative candidates and areas with large numbers of ethnic and visible minority voters. Three case studies of ridings that changed hands from the Liberals to the Conservatives after the 2011 federal election are looked at in-depth to explain why they changed hands and the impact that ethnic voters may have had on these results. Map 2 shows the locations of the three ridings. It is important to recall that the correlations presented in the previous sections represent the associational patterns of party support across the entire Toronto CMA and they cannot predict the associations in any individual riding.

\section{Case Study 1: Bramalea-Gore-Malton}

The riding of Bramalea-Gore-Malton is located in the northeast corner of the city of Brampton, bordering the cities of Toronto and Vaughan. Just over 100000 of its population of 160000 are visible minorities. The largest ethnic minority group by far is South Asians, making up over 66000 residents, with India being the main country of origin, at over 53000 . The second-largest group is Black visible minorities, at around 20 000 people.

All three parties ran candidates of Indian ethnic origin. The Liberal candidate was 5-time incumbent Gurbax Singh Malhi, who had represented the riding since 1993. The Conservatives ran Bal Gosal after running a non-Indian candidate in the previous election, and the NDP ran Jagmeet Singh Dhaliwal after running a different candidate of Indian ethnic origin in the 2008 election. 


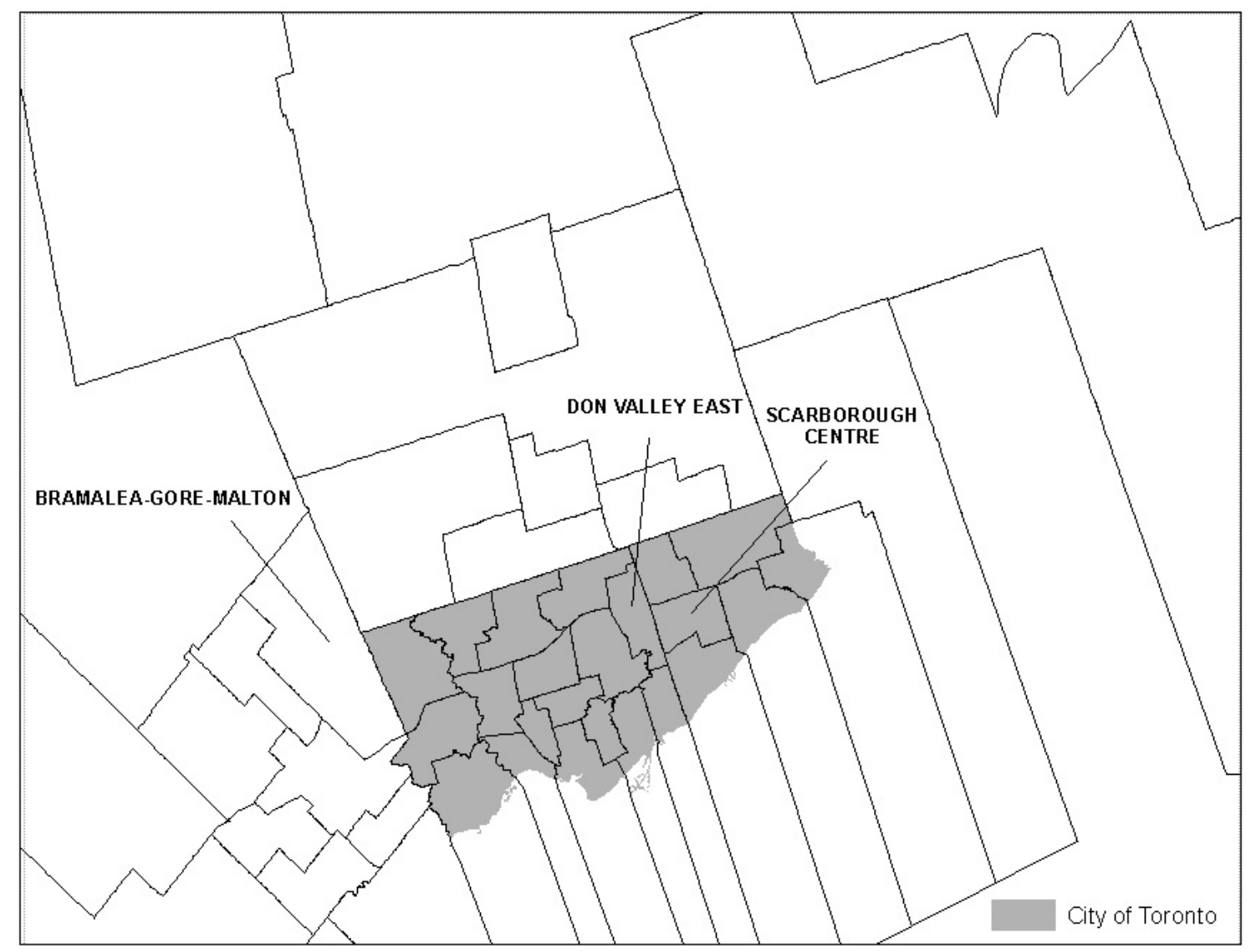

Table 5 shows the results of the election. The Liberal incumbent not only lost the election, but he came in third place. Gosal won the riding by a total of 539 votes over the NDP candidate and by over 3000 votes over the incumbent. In the 2008 election, a different Conservative candidate received $37.12 \%$ of the popular vote, so Conservative support in this riding actually dropped in the 2011 election.

Based on the election results for the entire CMA, the Liberals would have expected some, albeit non-significant positive association with East Indian voters in the 2011 election. The Conservatives were associated with significant negative support from Black visible minorities, who made up around one eighth of the total population of the riding, and no apparent association with South Asian and East India voters. Perhaps most 
surprisingly, the NDP candidate came in second despite the NDP not having any

association with either South Asian or Black visible minority voters. The NDP candidate would later leverage his strong federal showing into a success in the subsequent Ontario provincial election, winning the riding for the Ontario NDP.

Table 5 - 2011 Federal Election Results in Bramalea-Gore-Malton

$\begin{array}{llcc}\text { Party } & \text { Candidate } & \text { \# of Votes } & \% \text { of Votes } \\ \text { Conservative } & \text { Bal Gosal } & 19907 & 34.44 \% \\ \text { Liberal } & \text { Gurbax Singh Malhi } & 16402 & 29.40 \% \\ \text { NDP } & \text { Jagmeet Singh Dhaliwal } & 19368 & 33.51 \% \\ & \text { Turnout } & 58250 & 54.75 \%\end{array}$

\section{Case Study 2: Don Valley East}

Don Valley East is located in the north central part of the city of Toronto. Its population of around 109000 includes people from a variety of different ethnic origin and visible minority groups, with Chinese people being the largest with a population of around 21 000. Also of note are large populations of people of Southern European, Eastern European and South Asian, particularly East Indian ethnic origins. Around 63 000 , or about $58 \%$ of the residents of the riding are visible minorities.

The Liberal party had held the riding since 1993 and were running 2-term incumbent Yasmin Ratansi, who was the first Muslim woman elected to the House of Commons following her election in 2004. The Conservatives ran Joe Daniel and the NDP ran Mary Trapani Hynes, neither of whom have visible minority background.

Table 6 shows the results of the election. The Conservative candidate won over the Liberal incumbent by less than 1000 . The data shows that, across the CMA, the 
Liberals receive significant positive support from people of Eastern European ethnic origin, and positive but non-significant support from Southern Europeans, Chinese and South Asians and would be expected to win this riding. However, the Conservative candidate still won, despite negative associations with Chinese and South Asian voters, and positive but non-significant associations with Southern and Eastern Europeans.

Table 6 - 2011 Federal Election Results in Don Valley East

$\begin{array}{llll}\text { Party } & \text { Candidate } & \text { \# of Votes } & \% \text { of Votes } \\ \text { Conservative } & \text { Joe Daniel } & 14422 & 36.78 \% \\ \text { Liberal } & \text { Yasmin Ratansi } & 13552 & 34.56 \% \\ \text { NDP } & \text { Mary Trapani Hynes } & 9878 & 25.19 \% \\ & \text { Turnout } & 39430 & 57.24 \%\end{array}$

\section{Case Study 3: Scarborough Centre}

Scarborough Centre is located in the eastern part of the city of Toronto. It has a population of over 102000 people, of which around 63000 , or nearly $62 \%$ are visible minorities. It has a variety of different ethnic and visible minority origins, the biggest of which being South Asian, followed by Chinese, Southern European, Caribbean, and Filipino ethnic or visible minorities.

Liberal candidate John Cannis had held the riding since 1993. The Conservatives ran Roxanne James and the NDP ran Natalie Hundt. None of the candidates come from a visible minority background.

Table 7 shows the results of the election. In one of the more tightly contested races in the country, the three candidates were separated by just over 2000 votes, with the Conservative candidate coming out on top over the Liberal incumbent by about 1500 
votes, with the NDP candidate around 500 votes less than the Liberal candidate. The data shows that the Liberals would have expected positive, albeit non-significant support associated with all of the major ethnic and visible minority groups in the riding and therefore would have had the best chance to win. Instead, the Conservative candidate won despite the Conservatives having a negative but non-significant association with all of the major ethnic and visible minority groups with the exception of Southern Europeans, with whom they had a positive but non-significant relationship. The NDP candidate also had success in a losing effort, even though the NDP have no association either way with any of the ethnic and visible minority groups that make up the riding. Table 7 - 2011 Federal Election Results in Scarborough Centre

$\begin{array}{llll}\text { Party } & \text { Candidate } & \text { \# of Votes } & \text { \% of Votes / Turnout } \\ \text { Conservative } & \text { Roxanne James } & 13498 & 35.55 \% \\ \text { Liberal } & \text { John Cannis } & 12028 & 31.68 \% \\ \text { NDP } & \text { Natalie Hundt } & 11443 & 30.14 \% \\ & \text { Turnout } & 38184 & 55.25 \%\end{array}$

\section{Explaining the Conservative victories in the Greater Toronto Area}

As evidenced by the three case studies, Conservative victories in the Greater Toronto Area seemed to defy conventional logic. In all three cases, the Conservative candidate defeated a strong Liberal incumbent in ethnically diverse constituencies that had strong a NDP showing as well. There are four main patterns that emerge from the case studies that could explain some of the Conservative success.

Canada has a first-past-the-post electoral system; whichever candidate receives a plurality of votes is the winner, regardless of whether or not they receive the majority of 
votes. During the election, the NDP made a big leap forward, as the so-called "Orange Wave" captivated much of the country. Voters who would ordinarily vote Liberal may have chosen to support the NDP instead, as they had a strong surge towards the end of the election campaign and according some predictions, were poised to win the election. By choosing to vote NDP on election day, these voters took support away from the Liberal incumbent, allowing the Conservative candidate to take advantage of the split nonConservative vote to "come up the middle" to win the riding, despite having little more than one third of the total votes. For example, in Bramalea-Gore-Malton, the Conservative candidate beat the Liberal incumbent despite a drop in the popular vote compared to 2008, with the NDP candidate nearly tripling his percentag of the popular vote. In all three cases, the combined Liberal and NDP vote would have been enough to defeat the Conservative candidate. In addition to the three ridings that were studied indepth, this pattern is also present in Brampton West, Don Valley West, EglintonLawrence, Etobicoke Centre, Etobicoke - Lakeshore, Mississaugua - Brampton South, Mississaugua South, Mississaugua- Streetsville, Richmond Hill and Willowdale. While vote splitting is not a new phenomenon, it undervalues the votes received by the losing candidates, as the majority of the riding did not vote for the candidate that won the election. This also means that a relatively small swing shift of voters from one party to another can have a large impact on the election results.

Second, the voter turnout of all three ridings is below the national average of $61.1 \%$. As mentioned during the literature review, immigrants are less politically active than native-born Canadians and are less likely to vote. They have much less Canadian political experience to draw from and experience barriers to participating (White et. al., 
2006). In the context of Toronto municipal elections, Siemiatycki and Marshall (2012)

found that immigration and visible minority status had a strong negative relationship with voter turnout. This means that constituencies with more immigrants and visible minorities would expect to have less voter turnout. In the context of this study, this Siemiatycki and Marshall's observations seem to hold. Bramalea-Gore-Malton, where around a third of the population is East Indian, had a voter turnout of $54.75 \%$. The inverse of that (registered voters who did not vote) is $45.25 \%$. In theory, the entirety of the East Indian voting population could be included in the $45.25 \%$ who did not vote. East Indians have a positive, albeit non-significant association with support for the Liberal party. If they all stayed home on election day, this would easily explain the Liberal's change of fortune in Bramalea-Gore-Malton. Of course, it is very unlikely that the entirety of the East Indian population of Bramalea-Gore-Malton chose not to vote on election day, but this does highlight the importance of voter turnout. Even though the Liberal party may have thought that they could expect support from certain ethnic and visible minority groups, if those groups do not come out to vote then the Liberals would lose that advantage. The Conservatives, on the other hand, enjoy support from the well-established British and Canadian ethnic origin groups, who have no barriers to political participation. It is impossible to determine exactly who and who did not vote, but had there been $100 \%$ voter participation, the data shows that the Liberals likely would have prevailed in all three case studies.

Third, the results of the election show an increased divide between urban and suburban regions. As evidenced by Walks (2005), there is a "true political cleavage" between the inner city and the suburbs. Since the 1980s, there have been significant 
differences in voting behaviour between inner cities and suburbs, where inner city voting patterns are more to the left of the rest of the country, and suburban voting patters are more to the right (Walks, 2005). This is best evidenced by looking at Map 3, which looks at the results of the Toronto municipal election. The areas in grey are the wards where a plurality of the voters voted for Smitherman and the dotted areas for Ford. Clearly there is a divide; wards in the original, pre-amalgamation city of Toronto exclusively supported Smitherman, whereas the older suburban areas like North York, Etobicoke and Scarborough voted exclusively for Ford. As Hiebert (2000) points out, more and more immigrants are bypassing the inner city and its established immigrant-receiving areas and settling directly in the suburbs. The suburbanization of immigrants means that immigrants take on the policy concerns of suburban people, which would move their voting choices further to the right.

Finally, it is important to contextualize the data in light of the NDP surge in the 2011 federal election. Although the NDP experienced a historic leap into the political mainstream and Official Opposition status, the data does not favour the NDP in terms of support from ethnic and visible minority communities. The ridings in the GTA that the NDP won are all characterized by high levels of ethnic and visible minority diversity, but there is no dominant ethnic or visible minority group, rather many small and mediumsized communities. This spreads out NDP support among a variety of relatively small ethnic and visible minority communities within their constituencies, which individually have less impact than the large and dense suburban ethnic and visible minority communities. 
Map 3 - Results of 2010 Toronto Mayoral Election by Ward

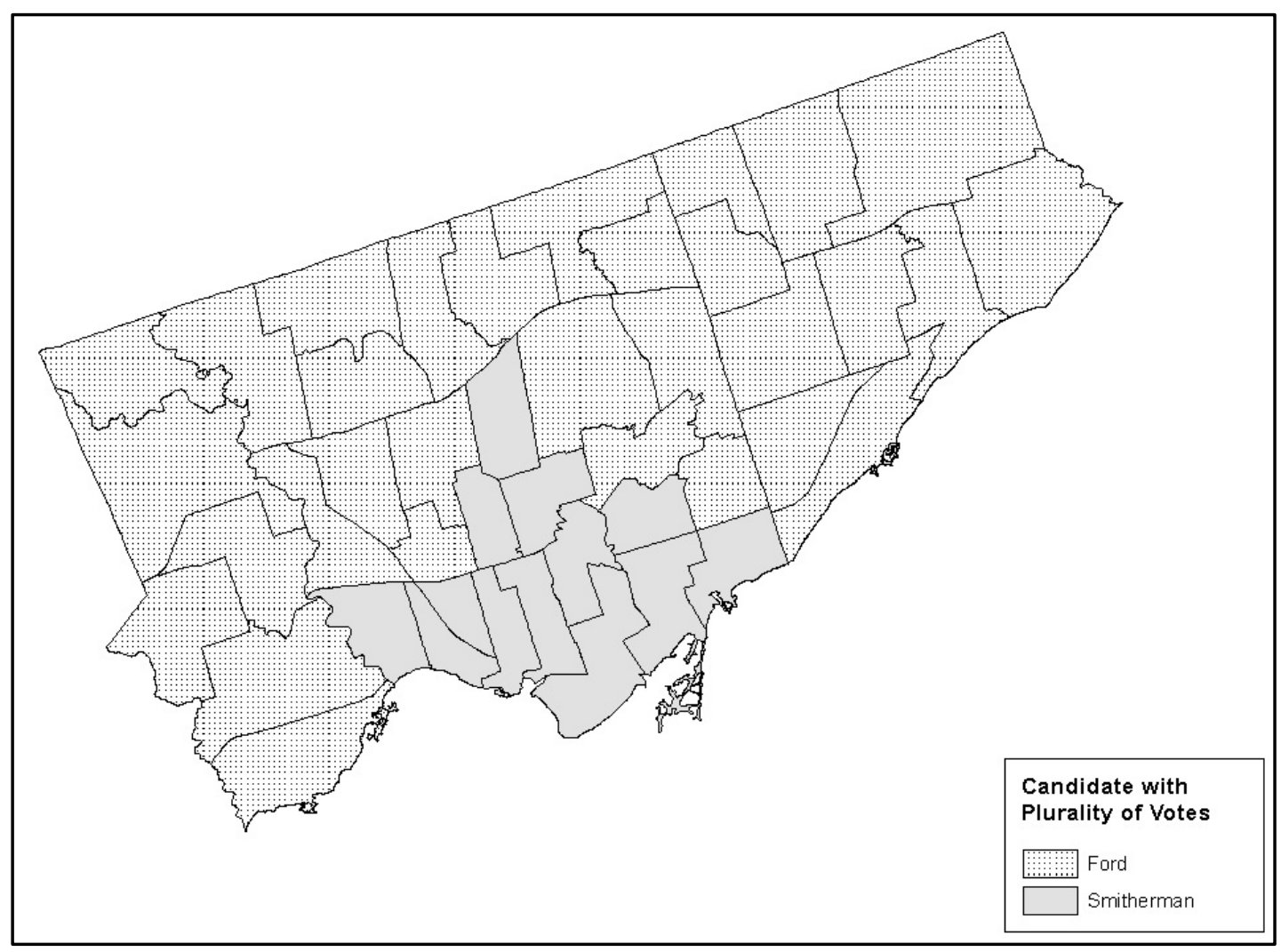




\section{CHAPTER 6}

\section{Conclusion and Future Directions}

\section{Applications for Future Research}

This research could easily be expanded to the national level to see whether the patterns of electoral association in the Greater Toronto Area are consistent in other municipalities. Furthermore, a smaller scale comparison of polling stations and their associated census tracts instead of an aggregate of the riding results would provide an even more accurate picture of ethnic and visible minority voting.

Second, changes in the socioeconomic and demographic composition of a riding potentially contribute to its partisan affiliation. Future research could look at changes in socioeconomic and demographic composition from census to census to see how these changes affect partisan affiliation, with an emphasis on changes in ethnic and visible minority composition. As part of that, it would be interesting to see how the partisan associations of immigrant and visible minority groups change as they become more integrated in Canadian culture. As they develop more of a Canadian identity, their partisan affiliations may change to resemble those of "Canadian" ethnic origin.

Finally, there is room to look at other non-political factors that might influence change in partisan affiliation in immigrant and visible minority communities. For example, in several of the ridings that the Conservative party took from the Liberals, they ran a candidate that came from the same ethnic or visible minority background of the most dominant group in 2011 when they did not do so in 2008. In a political world where engagement of immigrant communities is absolutely necessary, running candidates from 
ethnic and visible minority communities may be a major catalyst to support from the candidate's co-ethnic community.

\section{Conclusion: Looking Into the Future}

The data shows that Conservative victories in Toronto during the 2011 federal election may have been the result of a split non-Conservative vote and relatively low voter turnout, but there is a larger trend showing that the Liberal party is haemorrhaging support from ethnic and visible minority communities, which may prove to be their eventual downfall. As the Conservatives continue to work to engage ethnic and visible minority communities in Canada, the other two parties must find ways to solidify their electoral support in constituencies and get them out to vote. The mismatch between expected support and victory, especially for the Liberal party, speaks to a larger problem with the first-past-the-post system of electing representatives, where candidates can win a riding despite receiving less than a plurality of the votes.

The research also shows the potential for political parties to engage in Americanstyle campaigning, where their main focus is on mobilizing their supporters and affiliates to come out and vote on election day. Differences in voter turnout between the established bases of the Conservative and Liberal parties may account for the difference in as more than a dozen ridings in the Greater Toronto Area.

Immigrants will continue to make Canada their home, and they will continue to steep themselves in a Canadian political education. Immigrants may prove to be the deciding factor in elections to come, as the three parties fight to establish their brand in the minds of immigrants. Although the Conservative success in the Greater Toronto Area may have been a coincidence, it will be interesting to see how their success translates in 
the 2015 federal election, and whether the surge of the NDP will mean that more Liberalaffiliated immigrants will find another party that better represents them. 
APPENDIX A - Vote Totals by Riding for Federal Conservative, Liberal and NDP Candidates, 2008 and 2011

\begin{tabular}{|c|c|c|c|c|c|c|c|c|}
\hline Riding & Total11 & Con11 & Lib11 & NDP11 & Total08 & Con08 & Lib08 & NDP08 \\
\hline AJAX--PICKERING & 56455 & 24797 & 21569 & 8284 & 48862 & 18471 & 21675 & 4422 \\
\hline $\begin{array}{l}\text { BEACHES--EAST } \\
\text { YORK }\end{array}$ & 48862 & 11067 & 14967 & 20265 & 46465 & 7907 & 18967 & 14875 \\
\hline $\begin{array}{l}\text { BRAMALEA--GORE- } \\
\text {-MALTON }\end{array}$ & 58250 & 19907 & 16402 & 19368 & 49737 & 18353 & 22272 & 5945 \\
\hline BRAMPTON WEST & 63684 & 28320 & 22128 & 11225 & 54271 & 21515 & 21746 & 7334 \\
\hline $\begin{array}{l}\text { BRAMPTON-- } \\
\text { SPRINGDALE }\end{array}$ & 51370 & 24618 & 14221 & 10022 & 45689 & 17804 & 18577 & 5238 \\
\hline DAVENPORT & 39489 & 5573 & 10946 & 21096 & 35089 & 3838 & 15953 & 10896 \\
\hline DON VALLEY EAST & 39430 & 14422 & 13552 & 9878 & 37897 & 11777 & 18264 & 5062 \\
\hline $\begin{array}{l}\text { DON VALLEY } \\
\text { WEST }\end{array}$ & 53658 & 22963 & 22351 & 6280 & 50072 & 19441 & 22212 & 5102 \\
\hline $\begin{array}{l}\text { DUFFERIN-- } \\
\text { CALEDON }\end{array}$ & 48736 & 28674 & 6361 & 6409 & 44072 & 23363 & 8495 & 4385 \\
\hline DURHAM & 58184 & 31737 & 10387 & 12277 & 52998 & 28551 & 12167 & 5485 \\
\hline $\begin{array}{l}\text { EGLINTON-- } \\
\text { LAWRENCE }\end{array}$ & 48691 & 22652 & 18590 & 5613 & 43717 & 17073 & 19133 & 3663 \\
\hline $\begin{array}{l}\text { ETOBICOKE } \\
\text { CENTRE }\end{array}$ & 52794 & 21644 & 21618 & 7735 & 50475 & 18839 & 24537 & 4164 \\
\hline $\begin{array}{l}\text { ETOBICOKE } \\
\text { NORTH } \\
\end{array}$ & 32514 & 10357 & 13665 & 7630 & 31380 & 9436 & 15244 & 4940 \\
\hline $\begin{array}{l}\text { ETOBICOKE-- } \\
\text { LAKESHORE }\end{array}$ & 54763 & 21997 & 19128 & 11046 & 51235 & 17793 & 23536 & 5950 \\
\hline HALTON & 81394 & 44206 & 20903 & 12960 & 69674 & 32986 & 25136 & 6118 \\
\hline $\begin{array}{l}\text { MARI } \\
\text { UNIO }\end{array}$ & 50178 & 17734 & 19429 & 10897 & 45892 & 13885 & 25195 & 4682 \\
\hline $\begin{array}{l}\text { MISSISSAUGA } \\
\text { EAST-- } \\
\text { COOKSVILLE }\end{array}$ & 47314 & 18796 & 18120 & 8836 & 40781 & 13277 & 20457 & 4632 \\
\hline $\begin{array}{l}\text { MISSISSAUGA } \\
\text { SOUTH }\end{array}$ & 49652 & 22991 & 18393 & 6354 & 46550 & 18366 & 20518 & 4104 \\
\hline $\begin{array}{l}\text { MISSISSAUGA-- } \\
\text { BRAMPTON SOUTH }\end{array}$ & 53198 & 23632 & 18579 & 9465 & 44837 & 14664 & 21220 & 5268 \\
\hline $\begin{array}{l}\text { MISSISSAUGA-- } \\
\text { ERINDALE }\end{array}$ & 63671 & 29793 & 21541 & 10327 & 56071 & 23863 & 23446 & 4774 \\
\hline $\begin{array}{l}\text { MISSISSAUGA-- } \\
\text { STREETSVILLE }\end{array}$ & 50607 & 22104 & 18651 & 7834 & 47712 & 16985 & 21710 & 4710 \\
\hline $\begin{array}{l}\text { NEWMARKET-- } \\
\text { AURORA }\end{array}$ & 58421 & 31600 & 13908 & 8886 & 53227 & 24873 & 18250 & 4508 \\
\hline $\begin{array}{l}\text { OAK RIDGES-- } \\
\text { MARKHAM } \\
\end{array}$ & 90890 & 46241 & 25561 & 15229 & 76111 & 32028 & 31483 & 7126 \\
\hline OAKVILLE & 58411 & 30068 & 17890 & 8117 & 55363 & 26011 & 20528 & 4681 \\
\hline $\begin{array}{l}\text { PARKDALE--HIGH } \\
\text { PARK }\end{array}$ & 51161 & 7924 & 16757 & 24046 & 48384 & 5992 & 20705 & 17332 \\
\hline $\begin{array}{l}\text { PICKERING-- } \\
\text { SCARBOROUGH } \\
\text { EAST }\end{array}$ & 48072 & 19220 & 18013 & 8932 & 46194 & 14940 & 22874 & 4875 \\
\hline
\end{tabular}




\begin{tabular}{|l|r|r|r|r|r|r|r|r|}
\hline RICHMOND HILL & 50235 & 22078 & 17651 & 8433 & 45943 & 16318 & 21488 & 4526 \\
\hline $\begin{array}{l}\text { SCARBOROUGH } \\
\text { CENTRE }\end{array}$ & 38184 & 13498 & 12028 & 11443 & 36827 & 11088 & 17927 & 5801 \\
\hline $\begin{array}{l}\text { SCARBOROUGH } \\
\text { SOUTHWEST }\end{array}$ & 40501 & 12830 & 11699 & 14119 & 37217 & 10928 & 15486 & 6943 \\
\hline $\begin{array}{l}\text { SCARBOROUGH-- } \\
\text { AGINCOURT }\end{array}$ & 41016 & 13930 & 18498 & 7376 & 40477 & 11836 & 22795 & 3748 \\
\hline $\begin{array}{l}\text { SCARBOROUGH-- } \\
\text { GUILDWOOD }\end{array}$ & 38445 & 13158 & 13849 & 10145 & 36261 & 10881 & 18098 & 5183 \\
\hline $\begin{array}{l}\text { SCARBOROUGH-- } \\
\text { ROUGE RIVER }\end{array}$ & 46831 & 13935 & 12699 & 18935 & 40728 & 9160 & 23716 & 5954 \\
\hline SIMCOE--GREY & 64642 & 31784 & 8207 & 11185 & 56319 & 30897 & 12099 & 6288 \\
\hline ST. PAUL'S & 55471 & 17864 & 22409 & 12124 & 52032 & 13800 & 26326 & 6880 \\
\hline THORNHILL & 59947 & 36629 & 14125 & 7141 & 54395 & 26660 & 21448 & 3601 \\
\hline TORONTO CENTRE & 55890 & 12604 & 22832 & 16818 & 51563 & 9402 & 27462 & 7743 \\
\hline $\begin{array}{l}\text { TORONTO-- } \\
\text { DANFORTH }\end{array}$ & 48370 & 6885 & 8472 & 29235 & 45578 & 5287 & 13336 & 20323 \\
\hline TRINITY--SPADINA & 65611 & 10976 & 15276 & 35601 & 59796 & 8220 & 20967 & 24442 \\
\hline VAUGHAN & 68903 & 38533 & 20435 & 7940 & 56475 & 19390 & 27773 & 5442 \\
\hline $\begin{array}{l}\text { WELLINGTON-- } \\
\text { HALTON HILLS }\end{array}$ & 55309 & 35132 & 9034 & 7146 & 50651 & 29191 & 11312 & 4747 \\
\hline WILLOWDALE & 53554 & 22206 & 21245 & 9780 & 49085 & 15931 & 23889 & 5011 \\
\hline YORK CENTRE & 42320 & 20356 & 13979 & 6656 & 37189 & 14132 & 16164 & 4503 \\
\hline $\begin{array}{l}\text { YORK SOUTH-- } \\
\text { WESTON }\end{array}$ & 35486 & 8559 & 11542 & 14122 & 34731 & 7021 & 16071 & 9641 \\
\hline YORK WEST & 27991 & 6122 & 13030 & 7721 & 28840 & 4773 & 16997 & 5363 \\
\hline YORK--SIMCOE & 53067 & 33614 & 5703 & 10190 & 48345 & 27412 & 9044 & 5882 \\
\hline
\end{tabular}


APPENDIX B - Vote Totals by Riding for Ontario Provincial Progressive Conservative, Liberal and NDP Candidates, 2007 and 2011

\begin{tabular}{|c|c|c|c|c|c|c|c|c|}
\hline Riding & Total11 & $\mathrm{PC} 11$ & Lib11 & NDP11 & Total07 & $\mathrm{PC} 07$ & Lib07 & NDP07 \\
\hline $\begin{array}{l}\text { AJAX-- } \\
\text { PICKERING }\end{array}$ & 41446 & 14738 & 19606 & 5951 & 40778 & 13875 & 20218 & 3263 \\
\hline $\begin{array}{l}\text { BEACHES--EAST } \\
\text { YORK }\end{array}$ & 38447 & 5333 & 13813 & 17925 & 39900 & 6166 & 10215 & 17572 \\
\hline $\begin{array}{l}\text { BRAMALEA-- } \\
\text { GORE--MALTON }\end{array}$ & 43358 & 9775 & 14198 & 16318 & 40591 & 11819 & 11879 & 5077 \\
\hline $\begin{array}{l}\text { BRAMPTON } \\
\text { WEST }\end{array}$ & 49946 & 14421 & 19245 & 8337 & 44884 & 15111 & 20730 & 4893 \\
\hline $\begin{array}{l}\text { BRAMPTON-- } \\
\text { SPRINGDALE }\end{array}$ & 35270 & 12756 & 16663 & 5378 & 34710 & 10704 & 17526 & 3780 \\
\hline DAVENPORT & 31668 & 2593 & 13009 & 14504 & 29135 & 2841 & 12368 & 10865 \\
\hline $\begin{array}{l}\text { DON VALLEY } \\
\text { EAST }\end{array}$ & 31993 & 8604 & 16342 & 5953 & 35241 & 8821 & 19602 & 3757 \\
\hline $\begin{array}{l}\text { DON VALLEY } \\
\text { WEST }\end{array}$ & 41918 & 12828 & 24524 & 3611 & 45715 & 18136 & 23059 & 2135 \\
\hline $\begin{array}{l}\text { DUFFERIN-- } \\
\text { CALEDON } \\
\end{array}$ & 37183 & 17820 & 10008 & 5540 & 39464 & 16508 & 12636 & 6429 \\
\hline DURHAM & 45607 & 22392 & 13356 & 7990 & 45781 & 21485 & 14733 & 5519 \\
\hline $\begin{array}{l}\text { EGLINTON-- } \\
\text { LAWRENCE }\end{array}$ & 38324 & 12802 & 20807 & 3767 & 40240 & 15098 & 17324 & 4135 \\
\hline $\begin{array}{l}\text { ETOBICOKE } \\
\text { CENTRE }\end{array}$ & 42505 & 13952 & 21856 & 5099 & 45609 & 15565 & 22886 & 3828 \\
\hline $\begin{array}{l}\text { ETOBICOKE } \\
\text { NORTH }\end{array}$ & 933 & 6065 & 12082 & 5420 & 27654 & 5818 & 15167 & 4112 \\
\hline $\begin{array}{l}\text { ETOBICOKE-- } \\
\text { LAKESHORE }\end{array}$ & 43432 & 12679 & 22058 & 6781 & 44145 & 13524 & 20246 & 5991 \\
\hline HALTON & 58889 & 26145 & 23034 & 7756 & 54928 & 23391 & 22497 & 4159 \\
\hline $\begin{array}{l}\text { MARKHAM-- } \\
\text { UNIONVILLE }\end{array}$ & 37265 & 11690 & 19625 & 4584 & 35490 & 9581 & 21504 & 2599 \\
\hline $\begin{array}{l}\text { MISSISSAUGA } \\
\text { EAST-- } \\
\text { COOKSVILLE }\end{array}$ & 33915 & 11289 & 15450 & 5744 & 37655 & 8687 & 22207 & 3184 \\
\hline $\begin{array}{l}\text { MISSISSAUGA } \\
\text { SOUTH }\end{array}$ & 39994 & 14446 & 20244 & 4044 & 41026 & 2114 & 19195 & 2745 \\
\hline $\begin{array}{l}\text { MISSISSAUGA-- } \\
\text { BRAMPTON } \\
\text { SOUTH }\end{array}$ & 978 & 10285 & 5579 & 419 & 6702 & 9333 & 9738 & 3785 \\
\hline $\begin{array}{l}\text { MISSISSAUGA-- } \\
\text { ERINDALE }\end{array}$ & 45643 & 16294 & 20552 & 7768 & 4744 & 4838 & 21294 & 5117 \\
\hline $\begin{array}{l}\text { MISSISSAUGA-- } \\
\text { STREETSVILLE }\end{array}$ & 36079 & 10665 & 18591 & 5494 & 44537 & 1163 & 20316 & 4014 \\
\hline $\begin{array}{l}\text { NEWMARKET-- } \\
\text { AURORA }\end{array}$ & 37226 & 17201 & 13487 & 5477 & 45606 & 19435 & 18088 & 3285 \\
\hline $\begin{array}{l}\text { OAK RIDGES-- } \\
\text { MARKHAM }\end{array}$ & 64211 & 23569 & 28722 & 8444 & 59246 & 21369 & 28382 & 4801 \\
\hline OAKVILLE & 45146 & 17131 & 21711 & 4625 & 47794 & 16666 & 23757 & 3178 \\
\hline $\begin{array}{l}\text { PARKDALE-- } \\
\text { HIGH PARK }\end{array}$ & 39668 & 4668 & 14877 & 18365 & 40635 & 6013 & 11900 & 183136 \\
\hline
\end{tabular}




\begin{tabular}{|l|r|r|r|r|r|r|r|r|}
\hline $\begin{array}{l}\text { PICKERING-- } \\
\text { SCARBOROUGH } \\
\text { EAST }\end{array}$ & 39006 & 13033 & 18201 & 6424 & 40636 & 12884 & 19762 & 4563 \\
\hline $\begin{array}{l}\text { RICHMOND } \\
\text { HILL }\end{array}$ & 38393 & 13732 & 18040 & 4957 & 40671 & 14146 & 19443 & 3555 \\
\hline $\begin{array}{l}\text { SCARBOROUGH } \\
\text { CENTRE }\end{array}$ & 31838 & 7630 & 16150 & 6833 & 33066 & 8316 & 17714 & 4401 \\
\hline $\begin{array}{l}\text { SCARBOROUGH } \\
\text { SOUTHWEST }\end{array}$ & 33079 & 7061 & 14585 & 10404 & 32745 & 8363 & 15113 & 5920 \\
\hline $\begin{array}{l}\text { SCARBOROUGH- } \\
\text {-AGINCOURT }\end{array}$ & 31816 & 10222 & 14907 & 5017 & 33636 & 8495 & 19447 & 3589 \\
\hline $\begin{array}{l}\text { SCARBOROUGH- } \\
\text {-GUILDWOOD }\end{array}$ & 31890 & 9137 & 15606 & 6193 & 33928 & 9484 & 14413 & 7442 \\
\hline $\begin{array}{l}\text { SCARBOROUGH- } \\
\text {-ROUGE RIVER }\end{array}$ & 36464 & 6836 & 15275 & 13130 & 34318 & 4962 & 22362 & 4646 \\
\hline SIMCOE--GREY & 46604 & 25396 & 10386 & 6738 & 47731 & 24139 & 12428 & 4397 \\
\hline ST. PAUL'S & 42892 & 8971 & 25052 & 7121 & 44868 & 11910 & 21280 & 7061 \\
\hline THORNHILL & 44776 & 20982 & 18242 & 4016 & 48268 & 22153 & 20420 & 2656 \\
\hline $\begin{array}{l}\text { TORONTO } \\
\text { CENTRE }\end{array}$ & 45714 & 7149 & 25075 & 11495 & 45027 & 9225 & 21585 & 8528 \\
\hline $\begin{array}{l}\text { TORONTO-- } \\
\text { DANFORTH }\end{array}$ & 37044 & 3484 & 11358 & 19998 & 39123 & 4476 & 11410 & 17971 \\
\hline $\begin{array}{l}\text { TRINITY-- } \\
\text { SPADINA }\end{array}$ & 46909 & 5429 & 18731 & 19806 & 44915 & 6238 & 14170 & 18432 \\
\hline VAUGHAN & 49368 & 15409 & 26176 & 5584 & 46753 & 8773 & 28961 & 5417 \\
\hline $\begin{array}{l}\text { WELLINGTON-- } \\
\text { HALTON HILLS }\end{array}$ & 42270 & 23503 & 11326 & 6132 & 43789 & 21533 & 13311 & 3902 \\
\hline WILLOWDALE & 43207 & 14428 & 22034 & 5522 & 44153 & 15418 & 21065 & 3755 \\
\hline YORK CENTRE & 32328 & 11433 & 14696 & 4575 & 34235 & 11023 & 16428 & 3713 \\
\hline $\begin{array}{l}\text { YORK SOUTH-- } \\
\text { WESTON }\end{array}$ & 30987 & 3441 & 13805 & 13071 & 32225 & 3249 & 13812 & 13343 \\
\hline YORK WEST & 22635 & 2738 & 11444 & 7857 & 23951 & 2459 & 13180 & 6622 \\
\hline YORK--SIMCOE & 38794 & 20425 & 9596 & 6607 & 41467 & 19170 & 12784 & 4663 \\
\hline
\end{tabular}


APPENDIX C - Vote Totals by Ward for Toronto Mayoral Election Candidates, 2010

\begin{tabular}{|c|c|c|c|}
\hline Ward & Ford (Con) & Smitherman (Lib) & Pantalone (NDP) \\
\hline Beaches-East York (31) & 7942 & 6459 & 2889 \\
\hline Beaches-East York (32) & 7639 & 11812 & 3440 \\
\hline Davenport (17) & 6006 & 4407 & 2975 \\
\hline Davenport (18) & 3973 & 5697 & 3756 \\
\hline Don Valley East (33) & 7525 & 4465 & 1435 \\
\hline Don Valley East (34) & 8581 & 5403 & 1669 \\
\hline Don Valley West (25) & 9865 & 9138 & 1639 \\
\hline Don Valley West (26) & 8322 & 8272 & 1647 \\
\hline Eglinton-Lawrence (15) & 8923 & 4282 & 2388 \\
\hline Eglinton-Lawrence (16) & 8074 & 9505 & 1772 \\
\hline Etobicoke Centre (3) & 12913 & 4704 & 1563 \\
\hline Etobicoke Centre (4) & 14573 & 4728 & 1457 \\
\hline Etobicoke North (1) & 9435 & 2131 & 742 \\
\hline Etobicoke North (2) & 14325 & 2098 & 864 \\
\hline Etobicoke-Lakeshore (5) & 13789 & 7673 & 2170 \\
\hline Etobicoke-Lakeshore (6) & 11915 & 5894 & 2110 \\
\hline Parkdale-High Park (13) & 7679 & 10232 & 3599 \\
\hline Parkdale-High Park (14) & 4788 & 7949 & 3882 \\
\hline Scarborough Centre (37) & 10809 & 4892 & 1695 \\
\hline Scarborough Centre (38) & 10509 & 5107 & 1427 \\
\hline Scarborough East (43) & 8818 & 4557 & 1332 \\
\hline Scarborough East (44) & 12660 & 6262 & 1916 \\
\hline Scarborough Southwest (35) & 9390 & 4288 & 1880 \\
\hline Scarborough Southwest (36) & 9606 & 5682 & 2096 \\
\hline Scarborough-Agincourt (39) & 9519 & 3438 & 853 \\
\hline Scarborough-Agincourt (40) & 10094 & 4208 & 1410 \\
\hline Scarborough-Rouge River (41) & 11382 & 4638 & 949 \\
\hline Scarborough-Rouge River (42) & 10071 & 6798 & 1259 \\
\hline St. Paul's (21) & 5818 & 8979 & 2602 \\
\hline St. Paul's (22) & 7903 & 13411 & 2443 \\
\hline Toronto Centre-Rosedale (27) & 7068 & 17335 & 2909 \\
\hline Toronto Centre-Rosedale (28) & 4937 & 12513 & 2414 \\
\hline Toronto-Danforth (29) & 6493 & 7658 & 2863 \\
\hline Toronto-Danforth (30) & 5106 & 10492 & 3341 \\
\hline Trinity-Spadina (19) & 4630 & 9732 & 5801 \\
\hline Trinity-Spadina (20) & 5476 & 13151 & 4129 \\
\hline Willowdale (23) & 10959 & 8055 & 2181 \\
\hline Willowdale (24) & 9670 & 6181 & 1565 \\
\hline York Centre (9) & 7045 & 2155 & 1948 \\
\hline York Centre (10) & 9772 & 4458 & 1494 \\
\hline York South-Weston (11) & 9619 & 3511 & 1920 \\
\hline
\end{tabular}




\begin{tabular}{|l|l|l|r|}
\hline York South-Weston (12) & 7536 & 2747 & 1979 \\
\hline York West (7) & 7041 & 2233 & 1640 \\
\hline York West (8) & 5303 & 2502 & 1439 \\
\hline
\end{tabular}




\section{Reference List}

Almond, G., \& Verba, S. (1963). The Civic Culture. Princeton, NJ: Princeton University Press.

Anderson, C. D., \& Goodyear-Grant, E. (2008). Youth turnout: Adolescents' attitudes in Ontario. Canadian Journal of Political Science, 41(3), 697-718.

Bass, L. E., \& Casper, L. M. (2001). Differences in registering and voting between native-born and naturalized Americans. Population Research and Policy Review, 20(6), 483-511.

Berelson, B., Lazarsfeld, P., \& McPhee, W. (1954). Voting: A Study of Opinion Formation in a Presidential Campaign. Chicago: University of Chicago Press.

Bevelander, P., \& Pendakur, R. (2009). Social capital and voting participation of immigrants and minorities in Canada. Ethnic and Racial Studies, 32(8), 14061430 .

Black, J. H. (2009). The 2006 and 2008 Canadian federal elections and minority MPs. Canadian Ethnic Studies, 41(1), 69-93.

Blais, A. (2005). Accounting for the electoral success of the Liberal party in Canada: Presidential address to the Canadian political science association London, Ontario June 3, 2005. Canadian Journal of Political Science, 38(4), 821-840.

Bloemraad, I. (2008). Citizenship in the United States and Canada. Canadian Diversity, 6(4): 129-133.

Bueker, C.S. (2005). Political incorporation among immigrants from ten areas of origin: The persistence of source country effects. The International Migration Review, 39(1), 103-140.

Chareka, O., \& Sears, A. (2006). Civic duty: young people's conceptions of voting as a means of political participation. Canadian Journal of Education, 29(2), 521-540.

Chinchilla, N., \& Hamilton, N. (1999). Changing networks and alliances in a transnational context: Salvadoran and Guatemalan immigrants in southern California. Social Justice, 26(3), 4-26

Claes, E., Hooghe, M., \& Stolle, D. (2009). The political socialization of adolescents in Canada: Differential effects of civic education on visible minorities. Canadian Journal of Political Science, 42(3), 613-636.

Diebel, L. (2011, May 7). What really sunk Michael Ignatieff and the Liberals. The Toronto Star. Retrieved from 
http://www.thestar.com/news/canada/politics/article/987422--exclusive-whatreally-sunk-michael-ignatieff-and-the-liberals.

Elections Canada. (2012). Description of the national register of electors. From $\mathrm{http} / / / \mathrm{www}$. elections.ca/content.aspx?section=vot\&dir=reg/des\&document=index \&lang=e.

Gerber, L. M. (2006). The visible minority, immigrant, and bilingual composition of ridings and party support in the Canadian federal election of 2004(1). Canadian Ethnic Studies, 38(1), 65-82.

Gidengil, E., Fournier, P., Everitt, J., Nevitte, N. \& Blais, A. (2009). The anatomy of a Liberal defeat. In Annual Meeting of the Canadian Political Science Association. Carleton University, Ottawa.

Hero, R., Garcia, F. C., Garcia, J., \& Pachon, H. (2000). Latino participation, partisanship, and office holding. PS, Political Science \& Politics, 33(3), 529-534.

Hiebert, D. (2000). Immigration and the changing Canadian city. Canadian Geographer, 44(1), 25-43.

Kuitenbrouwer, P. (2010, November 5). How the mayoral race was won. The National Post. Retrieved from http://news.nationalpost.com/2010/11/05/peterkuitenbrouwer-how-the-mayoral-race-was-won/

Landolt, P., \& Goldring, L. (2010). Political cultures and transnational social fields: Chileans, Colombians and Canadian activists in Toronto. Global Networks, 10(4), 443-466.

Lapp, M. (1999). Ethnic group leaders and the mobilization of voter turnout: Evidence from five Montreal communities. Canadian Ethnic Studies, 31(2), 17-42.

Lenard, P. T. (2005). Belonging, political participation and ethno-cultural minorities. Canadian Foreign Policy, 12(3), 53-66,4-5.

Lopez, M. H., \& Marcelo, K. B. (2008). The civic engagement of immigrant youth: New evidence from the 2006 civic and political health of the nation survey. Applied Developmental Science, 12(2), 66-73.

McDevitt, M. (2006). The partisan child: developmental provocation as a model of political socialization. International Journal of Public Opinion Research, 18(1), 67-88. doi:10.1093/ijpor/edh079

Nakhaie, M. R. (2008). Social capital and political participation of Canadians. Canadian Journal of Political Science, 41(4), 835-860. 
Nicholson, S. P., Pantoja, A., \& Segura, G. M. (2006). Political knowledge and issue voting among the Latino electorate. Political Research Quarterly, 59(2), 259$266,268-271$.

O'Neill, T. (2006, January 30). Stephen in the middle. The Western Standard. Retrieved from http://www.westernstandard.ca/website/article.php?id=1394

Perla, H. (2010). A signal-flare strategy of transnational activism. NACLA Report on the Americas, 43(6), 27.

Putnam, R. 2000. Bowling Alone: The Collapse and Revival of American Community. New York: Simon \& Schuster.

Ramakrishnan, S. K., Wong, J., Lee, T., \& Junn, J. (2009). Race-based considerations and the Obama vote. Du Bois Review, 6(1), 219-238.

Shugart, M. S. (2004). Elections: The american process of selecting a president: A comparative perspective. Presidential Studies Quarterly, 34(3), 632-655.

Siemiatycki, M \& Marshall, S. (2012 unpublished). Denominators of difference: Immigrant voting in recent Toronto municipal elections. Ryerson University, Toronto.

Statistics Canada. (2011a). Ethnic diversity and immigration. From http://www.statcan.gc.ca/pub/11-402-x/2011000/chap/imm/imm-eng.htm.

Statistics Canada. (2011b). Reasons for not voting in the May 2, 2011 federal election. From http://www.statcan.gc.ca/daily-quotidien/110705/dq110705a-eng.htm.

Stoll, M. A., \& Wong, J. S. (2007). Immigration and civic participation in a multiracial and multiethnic Context1. The International Migration Review, 41(4), 880-908.

Torney-Purta, J., Barber, C. H., \& Wilkenfeld, B. (2007). Latino adolescents' civic development in the United States: Research results from the IEA civic education study. Journal of Youth and Adolescence, 36(2), 111-125.

Tossutti, L. (2007a). The electoral participation of ethnocultural communities. Working Paper Series on Electoral Participation and Outreach Practices: Elections Canada.

Tossutti, L. (2007b). Voluntary associations and the political engagement of young Canadians. Journal of Canadian Studies, 41(1), 100-125,230.

Walks, R. (2005). The city-suburban cleavage in Canadian federal politics. Canadian Journal of Political Science, 38(2), 383.

White, S., Nevitte, N., Blais,, A., Everitt, J.,Fournier, P., \& E. Gidengil. (2006). Making up for lost time: immigrant voter turnout in Canada. Electoral Insight 8 (2). 
White, S., Nevitte, N., Blais, A., Gidengil, E., \& Fournier, P. (2008). The political resocialization of immigrants: Resistance or lifelong learning? Political Research Quarterly, 61(2), 268-281.

Wolak, J. (2009). Explaining change in party identification in adolescence. Electoral Studies, 28(4), 573-583.

Wong, J. S. (2000). The effects of age and political exposure on the development of party identification among Asian American and Latino immigrants in the United States. Political Behavior, 22(4), 341-371.

Wong, J., \& Tseng, V. (2008). Political socialisation in immigrant families: Challenging top-down parental socialisation models. Journal of Ethnic and Migration Studies, 34(1), 151-168. 